\title{
The Effect of Wastewater Treatment Plants on Retainment of Plastic Microparticles to Enhance Water Quality-A Review
}

\author{
Rana Zeeshan Habib ${ }^{1}$, Ruwaya Al Kendi ${ }^{1}$, Thies Thiemann ${ }^{2 *}$ \\ ${ }^{1}$ Department of Biology, College of Science, United Arab Emirates University, Al Ain, United Arab Emirates \\ ${ }^{2}$ Department of Chemistry, College of Science, United Arab Emirates University, Al Ain, United Arab Emirates \\ Email: *thies@uaeu.ac.ae, *thiesthiemann@yahoo.de
}

How to cite this paper: Habib, R.Z., Al Kendi, R. and Thiemann, T. (2021) The Effect of Wastewater Treatment Plants on Retainment of Plastic Microparticles to Enhance Water Quality-A Review. Journal of Environmental Protection, 12, 161-195. https://doi.org/10.4236/jep.2021.123011

Received: January 27, 2021

Accepted: March 16, 2021

Published: March 19, 2021

Copyright $\odot 2021$ by author(s) and Scientific Research Publishing Inc. This work is licensed under the Creative Commons Attribution International License (CC BY 4.0). http://creativecommons.org/licenses/by/4.0/

\begin{abstract}
Microplastics, plastic pieces of $\leq 5 \mathrm{~mm}$ in size, are ubiquitous in ther environment and can be found in both terrestrial and aquatic ecosystems. This manuscript reviews the literature on the fate of microplastics in wastewater treatment and briefly highlights novel developments in the removal of microplastics from aqueous systems.
\end{abstract}

\section{Keywords}

Microplastics, Nanoplastics, Wastewater Treatment Plants, Sludge

Treatment, Plastic Retainment

\section{Introduction}

One year has passed since our first review on microplastics and wastewater treatment plants [1]. Since then, a number of other reviews on the topic have appeared [2]-[11] that complement reviews that had been there previously [12] [13] [14] [15] [16]. Nevertheless, the authors felt the need to extend the scope of the earlier review as it focused too much on plastic microbeads, an area of our research [17] at the time of writing, and too little on other forms of microplastics such as microtires [18] [19] and textile fibers [20] [21]. In addition, the contribution of the different sources of microplastics as found in the wastewater is changing over time, especially with the gradual phase-out of microplastic content in rinse-off cosmetics [22] [23] [24] and the ban in certain regions of plastic bags [25] and single use plastics [26], both potential materials for microplastics due to subsequent degradative fragmentation processes. Furthermore, there is continuous development and refinement of technologies to separate microplas- 
tics from wastewater that warrant reporting. It is for these reasons that the current review was drafted.

Microplastics (MPs) can be defined as plastic particles of $\leq 5 \mathrm{~mm}$ in size [27] [28] [29]. Also, the term nanoplastic (NP) has been used for particles $\leq 1 \mu \mathrm{m}$ in size [27] [30], although some authors define NPs as particles of up to $100 \mathrm{~nm}$ in size [31]. Here, the discussion is still ongoing [32]. These plastic particles have different sources. Some of the MP particles originate from the abrasive degradation of larger plastics such as from tyre materials and road-wear [33], clothing [34], plastic bags [35] and packaging [36], degradable over longer periods of time or even at the time of opening, and other larger pieces of plastic that are exposed to wear or weathering [37] [38] (Figure 1). These are called secondary MP. Then, there is the primary MP, which is materials that are produced at this small size for a specific purpose, micropellets in cosmetic formulations and in facial cleaners and body scrubs (median size of $0.2-0.4 \mathrm{~mm}$ ) [16] [39], microspherules in toothpastes (2 - $5 \mu \mathrm{m}$ in size) [40], microparticles in scrubbers used for air-blasting surfaces to remove paints and rust [41] [42] in paints and coatings [43], in detergents [43] and in drilling fluids in oil and gas exploration [1]. Recently, plastic micro-/nanoparticles have also been used in drug delivery systems [44] [45]. The amounts of materials used as primary MP and secondary MP stemming from the degradation of meso- and macroplastics on-land have been estimated in different studies commissioned by different European countries [43] [44] [46] [47] [48] and by the European Community [49]. The release of such materials, incl. of tyres, into sewage systems and as run-off into river systems or directly into the oceans has been estimated by different models, which sometimes took the known distribution of products other than MP as the basis for the models. Recently, the realization that such commonplace activities as using a tea-bag [50] or unwrapping a product [36] also lead to MP opens up further sources of such particles that need to be taken into account. Also, the atmospheric transfer of MP [51], which has been largely neglected until relatively recently, has been found to contribute to their accumulation in rivers, lakes [52] and oceans [53]. Much of the overall data on MP has been gained from overall a limited number of sampling studies at different locations, from which overall quantities of MP were derived using different models. It has been shown that different sampling techniques can lead to quite different results in the detection and quantification of MP in the environment [54] [55] and not in all areas is a consistent sampling technique for a matrix in use. In recent times, micro-Raman detection has been used to detect MP particles as small as $1 \mu \mathrm{m}$ in size [56]. This compares well with Fourier-transform infrared spectroscopy, where the size limit of the MP is said to be $10 \mu \mathrm{m}$. In former times, small microparticles and nanoparticles were less easy to detect. Z. Wang et al. have shown that in certain regions of the Yangtze delta, 1 - $5 \mu \mathrm{m}$ sized MPs make up to $58 \%$ of total, which were formerly left undetected. So, there is still a lot of uncertainty about the distribution of MP in the environment, both qualitatively and quantitatively. 


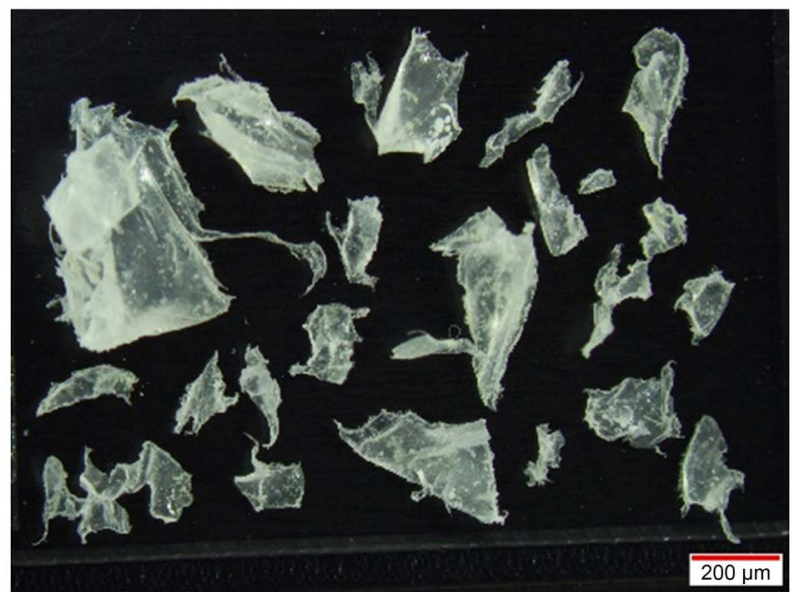

(A)

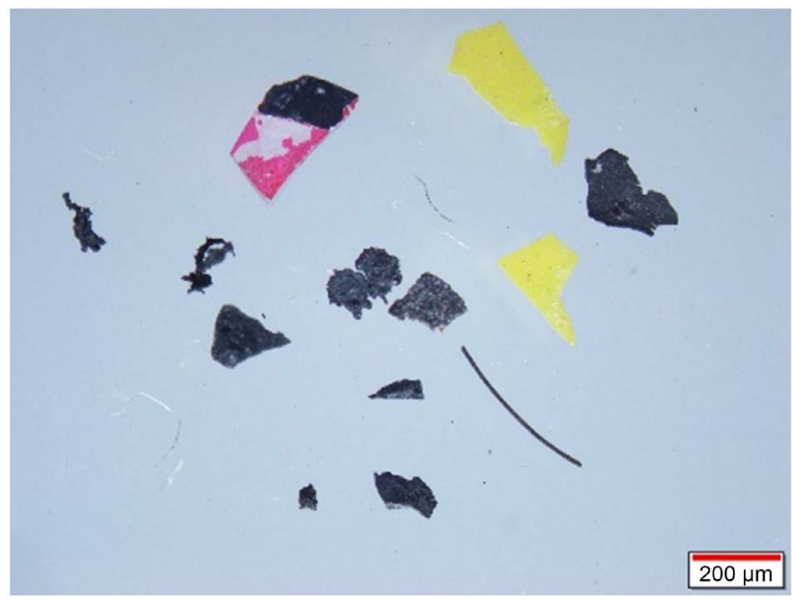

(B)

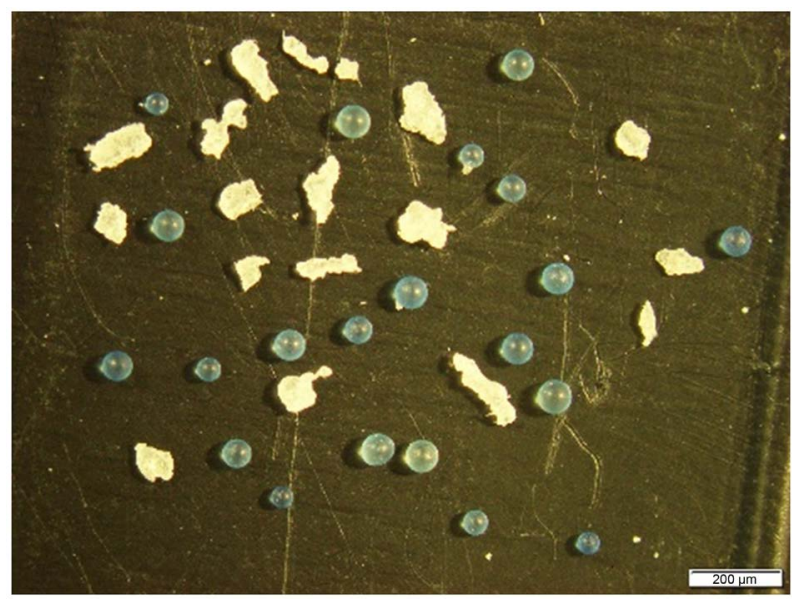

(C)

Figure 1. Various sources of microplastics that may end up in the municipal sewage system. (A) Microplastic from a meat-cutting board; (B) Microplastic from road dust; (C) Microplastic from rinse-off cosmetics.

Nevertheless, there are numbers in regard to MP that one can work with. One of the most extensive studies on MP in the environment has been forwarded by 
Eriksen et al. [57], where empirical data from 1571 locations taken in the years 2007-2013 has led to the estimation of 5 trillion $\left(5 \times 10^{12}\right)$ plastic pieces floating on the world's oceans, amounting to 268,940 tons, with $485 \times 10^{10}$ particles of less than $5 \mathrm{~mm}$ in size. Plastic particles, even initially positively buoyant particles [58] [59], can sink through the water column to the ocean floor [60], where it is generally accepted that the ocean floor serves as a sink for marine plastic [61] [62]. There could be as many as 35 times more MP on the ocean floor than on the ocean's surface, amounting to 4.4 million tons of MP in the top $9 \mathrm{~cm}$ of sediment throughout the world's oceans [63]. Between 1.15 and 2.41 million tons of plastic waste enter the oceans every year from rivers [64], with an estimated 4.8 to 12.7 million tons of plastic waste entering the oceans from land via all methods of transport, as of 2010 [65]. This number has been predicted to increase by an order of magnitude by 2050 [65]. Plastics degrade and mineralize very, very slowly [66]. It is known that microbes colonize plastics in an aquatic environment [67] [68]. Nevertheless, while they do help to biodegrade plastics, especially through the excretion of enzymes that catalyze chemical transformations in the plastic, even microorganisms (Zalerion maritimum [69], Bacillus cereus [70], B. gottheili [71]) specially selected through screening processes lead to a weight loss of various MPs consisting of PE, PET, PP or PS by less than $8 \%$ in 40 days. However, MPs can also serve as a transport for microorganisms that can damage ecosystems and/or affect living organisms negatively. In this context, it is interesting to note that the composition of microorganisms on MPs can change as they move through wastewater treatment plants (WWTPs) [71].

What is without doubt is that one major stream that carries MP and can pass them potentially on to the environment is municipal and industrial wastewater. Here, WWTPs act as a defense of last resort. Therefore, it is essential to know in how far WWTPs can retain MP under different treatment regimes. Published, extensive studies on the MP retaining ability of wastewater treatment plants started in earnest with the work of Browne et al. in 2011 [72], with data from the year before. In the years 2016-2020, a large body of work was published on the MP retaining ability of wastewater treatment plants from around the world.

Sewage sludge as a by-product of the water treatment, released into the environment, often carries a significant load of MP as well. It has been estimated that between 63,000 and 430,000 tons of MP are added via sewage sludge to European farmlands, annually [73] [74]. Already in 1998, Habib et al. reported on the presence of synthetic fibers in agricultural soils treated with sewage sludge [75]. This work has been expanded by other groups to non-fiber MP and the distribution and fate of MP in soils is a matter of pressing interest.

The current paper aims to review the effect of wastewater treatment plants on MP abundance in treated water dis-charged into the environment with a focus on the retaining ability of different types of wastewater treatment methods. Also, the fate of MPs in wastewater treatment plants is looked at. Furthermore, the review takes into account new methodologies to retain MP from aqueous media, developed in laboratories. 


\section{Wastewater Treatment Plants and Microplastic}

\subsection{Major Contributors to Microplastic Waste}

A major share of the microplastics entering the environment does so through sewage water. Some of the main contributors are microbeads from cosmetic formulations [76], textile fibers [77], and microtires and road wear particles (TRWP) [19]. Plastic microbeads in cosmetics are trending downward, as many countries have banned MP in many cosmetic products, such as in rinse-off cosmetics [78]. Nevertheless, products with MP content are still exported to countries where no ban is in place, even from countries that already have banned MP in the formulations [17] [79]. Fibers for the most part come from the shedding of particles during the washing process of textiles [72] [77] [80] [81]. Textile fibers are ubiquitous in the environment. We have found them in almost all samples that we have analysed, be they from lake shorelines, soil samples or even from commercially sold meat [82]. Nevertheless, in many regions, released textile fibers are for the most part natural fibers. Thus, Talvitie et al. have reported that the most common fibers emitted from a large wastewater treatment plant (WWTP) in Finland were natural (66\%), where (natural) cotton and (synthetic) polyester made the largest contribution with $44 \%$ and $33 \%$, respectively [83]. While natural fibers tend to degrade more quickly, organic pollutants can be adsorbed equally on synthetic and on natural fibers, where often textile fibers are impregnated with flame retardants. This can lead to an additional environmental impact. Tire and roadwear particles constitute a main contributor of plastic microparticles in the environment. While tire and roadwear particles have been investigated for a long time from a road safety point of view, their environmental impact has come to the fore only relatively recently [19]. Models have shown that appreciable amounts of microplastics from TRWP are swept into surface waters [84] [85], where a recent calculation showed that $8700-19,800$ tons per year of TRWP, amounting to $12 \%-20 \%$ of the emitted total, reach surface water, alone in Germany [86]. Tyres are known to be very complex constructs, incorporating many small organic molecules. These are released [87] over time when tyre particles are discharged into the environment. A recent study in this regard has shown that the slow release of $\mathrm{N}$-(1,3-dimethylbutyl)-N'-phenyl-pphenylenediamine) (6PPD), a globally used tire rubber antioxidant, is most likely to blame for the acute mortality in adult coho salmon on the US west coast [88]. Phthalates are also often associated with microplastics as with plastics in general [87] [89]. Also of interest to the evaluation of wastewater treatment plants is that it has been estimated that $1400-2800$ tons per year of TWP are currently deposited on agricultural areas. Again, this is for Germany, alone [86].

\subsection{Studies of MP Retainment by Wastewater Treatment Plants around the World}

Municipal wastewater treatment facilities are typically designed based upon a common schematic (Figure 2), though each facility will differ slightly in the exact 


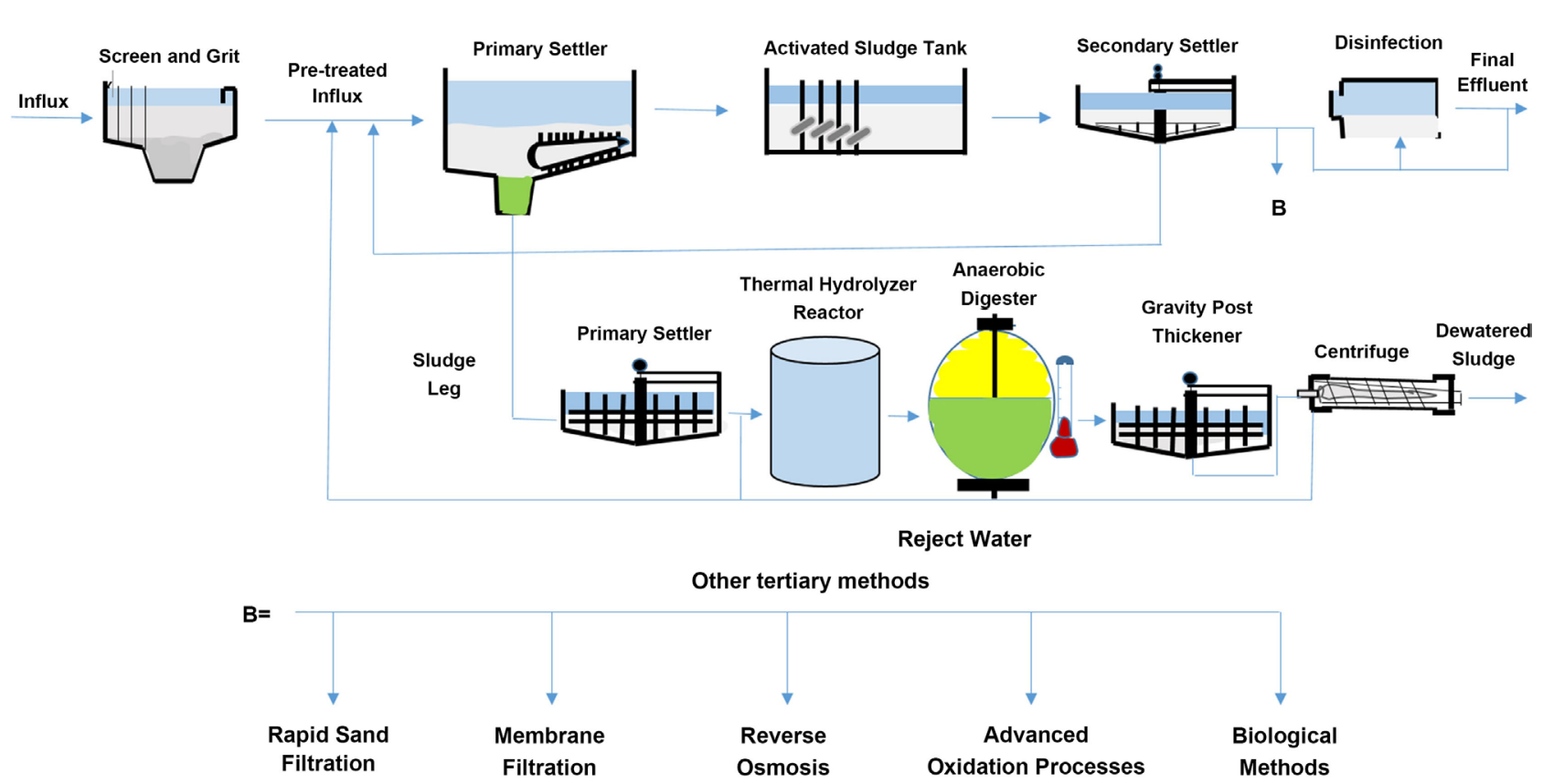

Figure 2. Possible set-up of a wastewater treatment plant.

configuration of this same basic design. Pre-treatment and primary treatment remove large debris items with screen mesh sizes of $6 \mathrm{~mm}$ or larger. Screen of mesh size between 3 and $10 \mathrm{~mm}$ is called fine screening. This together with the grit and primary clarifier can reduce the MP content of the influent by up to $45 \%$, especially catching MPs with density different from water. Therefore, the pre-treatment and primary treatment play a significant role in the removal of MPs, especially those of $100 \mu \mathrm{m}-5000 \mu \mathrm{m}$ in size [16] [90] [91] [92]. Secondary treatment removes suspended and dissolved organic material and nutrients, largely through the incorporation of microorganisms within large aeration tanks. Extracellular polymer substances (EPS) from microorganisms are capable of catching MPs that then become entrapped in the sludge. Flocculates and settling tanks help separate the sewage sludge from the post-processing effluent (hereafter simply "effluent") prior to any disinfection, polishing or advanced (tertiary) treatment. Here, about $50 \%$ of MPs are caught, trapped by sinking flocculates or in floating oil and grease [16] [83] [93] [94]. The tertiary stage can include further coagulation or filtration steps. Usually, the resulting effluent is discharged into a nearby waterbody. Thus, most MPs end up the sewage sludge [14], which in many cases undergoes a digestion process.

Over the last 7 years, studies on the retainment and release of MP by wastewater treatment plants have been published for close to 70 locations worldwide (Figure 3 and Table 1 [72] [83] [90]-[146]). Again, sampling strategies and analytical methods used have an effect on the quantification of MP fluxes through WWTPs [147] [148]. Thus, Murphy et al. collected bulk samples and then used a sieving step (65 $\mu \mathrm{m}$ mesh size) [90], while Carr et al. [99] fixed stacked sieves $(400-445 \mu \mathrm{m})$ in a wastewater stream to sample for MPs. Sampling can vary from grab sampling [72] [83] [90] [96] [100] [101] [103] [127], 
Table 1. Studies of microplastics (MP) in wastewater treatment plants (WWTPs) around the world.

\begin{tabular}{|c|c|c|c|c|c|c|c|}
\hline Ref. & $\begin{array}{l}\text { MP conc. } \\
\text { in influents }\end{array}$ & $\begin{array}{l}\text { MP conc. } \\
\text { in effluent }\end{array}$ & $\begin{array}{c}\text { Lower size } \\
\text { limit for } \\
\text { fractionation } \mu \mathrm{m}\end{array}$ & WWTP type & $\begin{array}{l}\text { Retention/ } \\
\text { Efficiency }\end{array}$ & $\begin{array}{l}\text { Analytical } \\
\text { Method }\end{array}$ & Country \\
\hline $\begin{array}{c}\text { Lares et al., } 2018 \\
\text { [95] }\end{array}$ & $57.6 \mathrm{MP} / \mathrm{L}$ & 1.05 part./L & 250 & $\begin{array}{c}\text { Primary and } \\
\text { secondary }\end{array}$ & $98.3 \%$ & $\begin{array}{l}\text { FTIR and Raman } \\
\text { Microscope }\end{array}$ & $\begin{array}{l}\text { Finland } \\
\text { (Mikkeli) }\end{array}$ \\
\hline $\begin{array}{c}\text { Dyachenko et al., } \\
\quad 2017 \text { [97] }\end{array}$ & n.a & 0.02 part./L & 125 & $\begin{array}{c}\text { Primary, } \\
\text { secondary } \\
\text { and tertiary }\end{array}$ & n.a. & n.a & USA \\
\hline $\begin{array}{c}\text { Mason et al., } 2016 \\
{[98]}\end{array}$ & n.a & 0.05 part./L & 125 & $\begin{array}{c}17 \text { WWTPs, } \\
\text { Tertiary }\end{array}$ & n.a. & Microscope & USA \\
\hline $\begin{array}{c}\text { Murphy et al., } \\
2016 \text { [90] }\end{array}$ & $15.70 \mathrm{MP} / \mathrm{L}$ & 0.25 part. $/ \mathrm{L}$ & 11 & Secondary & $98.4 \%$ & FTIR & UK \\
\hline $\begin{array}{c}\text { Carr et al., } 2016 \\
{[99]}\end{array}$ & $\begin{array}{c}1.10 \times 10^{9} / \text { day } \\
(681 \text { million } \\
\text { L./day })\end{array}$ & 0.88 part. $/ \mathrm{m}^{3}$ & 45 & $\begin{array}{l}\text { Secondary and } \\
\text { Tertiary }\end{array}$ & $99.9 \%$ & $\begin{array}{l}\text { Visual sorting, } \\
\text { Microscope } \\
\text { FTIR }\end{array}$ & USA \\
\hline $\begin{array}{l}\text { Ziajahromi et al., } \\
\quad 2017 \text { [93] }\end{array}$ & n.a & 0.28 part./L & 25 & $\begin{array}{l}\text { Primary, } \\
\text { secondary } \\
\text { and tertiary }\end{array}$ & $92 \%-99 \%$ & ATR-FT-IR & Australia \\
\hline $\begin{array}{l}\text { Michielssen et al., } \\
2016[100]\end{array}$ & $367 \mathrm{MP} / \mathrm{L}$ & $0.5 \mathrm{MP} / \mathrm{L}$ & 20 & $\begin{array}{c}\text { Tertiary } \\
\text { (AnMBR) }\end{array}$ & $99.4 \%$ & $\begin{array}{l}\text { Visual sorting, } \\
\text { Microscope }\end{array}$ & $\begin{array}{c}\text { USA } \\
\text { (Northfield) }\end{array}$ \\
\hline $\begin{array}{c}\text { Mintenig et al., } \\
2014 \text { and } 2017 \\
{[94][101]}\end{array}$ & n.a & 0.1 to $10.1 \mathrm{MP} / \mathrm{L}$ & 20 & $\begin{array}{l}12 \text { WWTPs: } \\
\text { mostly secondary } \\
\text { and tertiary }\end{array}$ & $97 \%$ & micro-FT-IR & $\begin{array}{c}\text { Germany } \\
\text { (Oldenburg) }\end{array}$ \\
\hline $\begin{array}{c}\text { Talvitie et al., } \\
2015 \text { [102] }\end{array}$ & $610 \mathrm{MP} / \mathrm{L}$ & $\begin{array}{l}13.5 \mathrm{MP} / \mathrm{L} \text { (incl. all } \\
\text { textile fibers) }\end{array}$ & 20 & $\begin{array}{c}\text { Primary, } \\
\text { secondary } \\
\text { and tertiary }\end{array}$ & $97.6 \%$ & $\begin{array}{l}\text { Visual sorting, } \\
\text { Stereo- } \\
\text { microscope }\end{array}$ & $\begin{array}{c}\text { Finland } \\
\text { Viikinmäki }\end{array}$ \\
\hline $\begin{array}{c}\text { Talvitie et al., } \\
2017 \text { [114] }\end{array}$ & 6.9 & $0.005 \mathrm{MP} / \mathrm{L}$ & 20 & 4 tertiary WWTPs & $99.9 \%$ & $\begin{array}{l}\text { Visual sorting, } \\
\text { Stereo- } \\
\text { microscope }\end{array}$ & Finland \\
\hline $\begin{array}{c}\text { Leslie et al., } 2017 \\
{[104]}\end{array}$ & $73 \mathrm{MP} / \mathrm{L}$ & 9 to $91 \mathrm{MP} / \mathrm{L}$ & 0.7 & 7 WWTPs & $72 \%$ & $\begin{array}{c}\text { Visual sorting } \\
\text { FTIR }\end{array}$ & Netherlands \\
\hline $\begin{array}{c}\text { Browne et al., } \\
2011 \text { [72] }\end{array}$ & n.a & $1 \mathrm{MP} / \mathrm{L}$ & (filtered) & $\begin{array}{l}\text { Primary, } \\
\text { secondary and } \\
\text { tertiary }\end{array}$ & n.a. & n.a & Australia \\
\hline $\begin{array}{c}\text { Dris et al., } 2015 \\
{[91]}\end{array}$ & n.a & 14 to $50 \mathrm{MP} / \mathrm{L}$ & 100 & Secondary & $83 \%-95 \%$ & Visual sorting & France \\
\hline $\begin{array}{c}\text { Carr et al., } 2016 \\
\text { [99] }\end{array}$ & $1 \mathrm{MP} / \mathrm{L}$ & $90 \mathrm{MP} / \mathrm{L}$ & $90-300$ & $\begin{array}{l}\text { Primary, } \\
\text { secondary and } \\
\text { tertiary }\end{array}$ & $95 \%-99 \%$ & & USA \\
\hline $\begin{array}{c}\text { Talvitie and } \\
\text { Heinonen } 2014 \\
{[105]}\end{array}$ & $627 \mathrm{MP} / \mathrm{L}$ & $70 \mathrm{MP} / \mathrm{L}$ & 20 & n.a & $95.6 \%$ & $\begin{array}{c}\mu \text {-Raman } \\
\text { spectroscopy } \\
\text { Microscope }\end{array}$ & Russia \\
\hline $\begin{array}{c}\text { Gündoğdu et al., } \\
2018 \text { [106] }\end{array}$ & $4,825,697 /$ day & $7.02 \mathrm{MP} / \mathrm{L}$ & n.a. & Secondary & $73 \%$ & $\begin{array}{c}\text { Visual and } \\
\mu \text {-Raman } \\
\text { spectroscopy }\end{array}$ & $\begin{array}{l}\text { Turkey } \\
\text { (Seyhan) }\end{array}$ \\
\hline $\begin{array}{l}\text { Gündoğdu et al., } \\
2018 \text { [106] }\end{array}$ & $2,040,639 /$ day & $4.11 \mathrm{MP} / \mathrm{L}$ & n.a. & Secondary & $79 \%$ & $\begin{array}{c}\text { Visual and } \\
\mu \text {-Raman } \\
\text { spectroscopy }\end{array}$ & $\begin{array}{l}\text { Turkey } \\
\text { (Yüreğir) }\end{array}$ \\
\hline
\end{tabular}




\section{Continued}

\begin{tabular}{|c|c|c|c|c|c|c|c|}
\hline $\begin{array}{c}\text { Estahbanadi and } \\
\text { Fahrenfeld } 2016 \\
\text { [118] }\end{array}$ & n.a & 0.028 to $0.44 \mathrm{MP} / \mathrm{L}$ & $250-500$ & $\begin{array}{l}\text { Primary and } \\
\text { secondary }\end{array}$ & n.a. & $\begin{array}{l}\text { Visual sorting, } \\
\text { Microscope }\end{array}$ & USA \\
\hline $\begin{array}{l}\text { Kalčiková et al., } \\
2017 \text { [107] }\end{array}$ & n.a & $0.021 \mathrm{MP} / \mathrm{L}$ & 37 to 95 & $\begin{array}{c}\text { Primary } \\
\text { (Mechanical and } \\
\text { Biological) }\end{array}$ & $87 \%$ & FT-IR & Slovenia \\
\hline $\begin{array}{c}\text { Simon et al., } 2018 \\
\text { [113] }\end{array}$ & $7216 \mathrm{MP} / \mathrm{L}$ & $54 \mathrm{MP} / \mathrm{L}$ & 10 to 500 & - & $98.3 \%$ & FPA-FTIR & Denmark \\
\hline $\begin{array}{c}\text { Sutton et al., } 2016 \\
\text { [92] }\end{array}$ & n.a & $0.086 \mathrm{MP} / \mathrm{L}$ & 125 & $\begin{array}{c}\text { Primary and } \\
\text { secondary }\end{array}$ & n.a. & $\begin{array}{c}\text { Dissection } \\
\text { microscope and } \\
\text { Raman } \\
\text { spectroscopy }\end{array}$ & USA \\
\hline $\begin{array}{l}\text { Michielssen et al., } \\
2016[100]\end{array}$ & 133.0 MP/L & $5.9 \mathrm{MP} / \mathrm{L}$ & 20 & $\begin{array}{c}\text { Primary and } \\
\text { secondary }\end{array}$ & $93.8 \%$ & $\begin{array}{l}\text { Visual sorting, } \\
\text { Microscope }\end{array}$ & USA (Detroit) \\
\hline $\begin{array}{l}\text { Michielssen et al., } \\
2016 \text { [100] }\end{array}$ & $367 \mathrm{MP} / \mathrm{L}$ & $2.6 \mathrm{MP} / \mathrm{L}$ & 20 & $\begin{array}{l}\text { Primary, } \\
\text { secondary } \\
\text { and tertiary }\end{array}$ & $97.2 \%$ & $\begin{array}{l}\text { Visual sorting, } \\
\text { Microscope }\end{array}$ & $\begin{array}{c}\text { USA } \\
\text { (Northfield) }\end{array}$ \\
\hline $\begin{array}{c}\text { Gies et al., } 2018 \\
\text { [119] }\end{array}$ & $31.1 \mathrm{MP} / \mathrm{L}$ & $0.5 \mathrm{MP} / \mathrm{L}$ & 64 & $\begin{array}{l}\text { Primary } \\
\text { and secondary }\end{array}$ & $98.3 \%$ & $\begin{array}{l}\text { Microscopy and } \\
\text { FT-IR }\end{array}$ & Canada \\
\hline $\begin{array}{l}\text { Wisniowska et al., } \\
\quad 2018 \text { [120] }\end{array}$ & $\begin{array}{c}19.4 \cdot 10^{3} \text { to } \\
552.2 \cdot 10^{3} \mathrm{MP} / 1 \mathrm{~m}^{3}\end{array}$ & 0.028 to $0.96 \mathrm{MP} / \mathrm{L}$ & n.a. & n.a. & $95 \%-99 \%$ & n.a & Poland \\
\hline $\begin{array}{c}\text { Yang et al., } 2019 \\
{[121]}\end{array}$ & $12.03 \mathrm{MP} / \mathrm{L}$ & $0.59 \mathrm{MP} / \mathrm{L}$ & 50 & $\begin{array}{c}\text { Primary } \\
\text { and secondary }\end{array}$ & $95 \%$ & $\begin{array}{l}\text { Microscopy } \\
\text { and FT-IR }\end{array}$ & $\begin{array}{l}\text { China } \\
\text { (Beijing) }\end{array}$ \\
\hline $\begin{array}{c}\text { Bayo et al., } 2019 \\
{[122]}\end{array}$ & $15.70 \mathrm{MP} \cdot \mathrm{L}^{-1}$ & $0.25 \mathrm{MP} / \mathrm{L}$ & n.a & Primary & $90.3 \%$ & $\begin{array}{l}\text { Microscopy } \\
\text { and FT-IR }\end{array}$ & $\begin{array}{c}\text { Spain } \\
\text { (Cartagena) }\end{array}$ \\
\hline $\begin{array}{c}\text { Long et al., } 2019 \\
{[123]}\end{array}$ & $1.57-13.69 \mathrm{MP} / \mathrm{L}$ & $0.20-1.73 \mathrm{MP} / \mathrm{L}$ & 28.3 & $\begin{array}{c}\text { Primary } \\
\text { and secondary }\end{array}$ & $97.8 \%$ & $\begin{array}{l}\text { Visual sorting } \\
\text { and } \\
\text { micro-Raman } \\
\text { spectroscopy }\end{array}$ & China \\
\hline $\begin{array}{c}\text { Blair et al., } 2019 \\
\text { [111] }\end{array}$ & 3 and $10 \mathrm{MP} \cdot \mathrm{L}^{-1}$ & $<1$ and $3 \mathrm{MP} / \mathrm{L}$ & 300 & Tertiary & $96 \%$ & FT-IR & UK \\
\hline $\begin{array}{c}\text { Xu et al., } 2019 \\
{[124]}\end{array}$ & $196.00 \mathrm{MP} / \mathrm{L}$ & $9.04 \mathrm{MP} / \mathrm{L}$ & 1000 & $\begin{array}{l}\text { Primary } \\
\text { and secondary }\end{array}$ & $97.2 \%$ & ATR-FTIR & $\begin{array}{c}\text { China } \\
\text { (Changzhu) }\end{array}$ \\
\hline $\begin{array}{c}\text { Lv et al., } 2019 \\
{[125]}\end{array}$ & $0.28 \mathrm{mp} / \mathrm{L}$ & 0.13 and $0.05 \mathrm{MP} / \mathrm{L}$ & 25 & n.a. & MBR 99.5\%, & FTIR & China \\
\hline $\begin{array}{c}\text { Liu et al., } 2019 \\
{[126]}\end{array}$ & $80 \mathrm{MP} / \mathrm{L}$ & $28.4 \mathrm{MP} / \mathrm{L}$ & 100 & $\begin{array}{c}\text { Primary } \\
\text { and secondary }\end{array}$ & $64.4 \%$ & $\begin{array}{l}\text { Visual inspection } \\
\text { and FTIR }\end{array}$ & China \\
\hline $\begin{array}{c}\text { Wolff et al., } 2019 \\
{[127]}\end{array}$ & n.a & 59 and $30 \mathrm{MP} / \mathrm{L}$ & 10 & $\begin{array}{c}\text { Primary } \\
\text { and secondary }\end{array}$ & n.a & $\begin{array}{c}\text { Raman } \\
\text { spectroscopy }\end{array}$ & Germany \\
\hline $\begin{array}{c}\text { Conley et al., }{ }^{2019}{ }_{1} \\
{[112]}\end{array}$ & $147,126,146 \mathrm{MP} / \mathrm{L}$ & $\begin{array}{c}3.7,17.6 \\
\text { and } 17.2 \mathrm{MP} / \mathrm{L}\end{array}$ & 23 & $\begin{array}{c}\text { Primary } \\
\text { and secondary }\end{array}$ & $\begin{array}{c}97.6 \%, \\
85.2 \%, 85.5 \%\end{array}$ & $\begin{array}{c}\text { Visual } \\
\text { Observation and } \\
\text { stereomicro- } \\
\text { scope }\end{array}$ & USA \\
\hline $\begin{array}{c}\text { Magni et al., } 2019 \\
\text { [115] }\end{array}$ & $2.5 \mathrm{MP} / \mathrm{L}$ & $0.4 \mathrm{MP} / \mathrm{L}$ & 8 & $\begin{array}{l}\text { Primary, } \\
\text { secondary } \\
\text { and tertiary }\end{array}$ & $84 \%$ & FTIR & Italy \\
\hline $\begin{array}{c}\text { Ren et al., } 2020 \\
{[108]}\end{array}$ & $16.0 \mathrm{MP} / \mathrm{L}$ & $2.9 \mathrm{MP} / \mathrm{L}$ & $0.08-0.55 \mathrm{~mm}$ & $\begin{array}{c}\text { Primary, } \\
\text { secondary } \\
\text { and tertiary }\end{array}$ & $81.9 \%$ & $\begin{array}{l}\text { Visual inspection } \\
\text { and Microscope }\end{array}$ & $\begin{array}{c}\text { China } \\
\text { (Zhengzhou) }\end{array}$ \\
\hline
\end{tabular}




\section{Continued}

\begin{tabular}{|c|c|c|c|c|c|c|c|}
\hline $\begin{array}{l}\text { Ziajahromi et al., } \\
\quad 2021 \text { [128] }\end{array}$ & n.a & $\begin{array}{c}22.1 \times 10^{6} \text { to } 133 \times 10^{6} \\
\text { per day }\end{array}$ & $>25 \mu \mathrm{m}$ & n.a & $\begin{array}{l}99.8 \%- \\
98.2 \%\end{array}$ & $\begin{array}{c}\text { Visual } \\
\text { Observation } \\
\text { and FT-IR }\end{array}$ & Australia \\
\hline $\begin{array}{l}\text { Wei et al., } 2020 \\
{[129]}\end{array}$ & $430-2154 \mathrm{MP} / \mathrm{m}^{3}$. & $430-2154 \mathrm{MP} / \mathrm{m}^{3}$ & $0.0308-0.1 \mathrm{~mm}$ & RD-WWTFs & $84 \%$ & $\begin{array}{l}\text { Micro-Raman } \\
\text { spectroscopic }\end{array}$ & $\begin{array}{c}\text { China } \\
\text { (Hangzhou) }\end{array}$ \\
\hline $\begin{array}{l}\text { Petroody et al., } \\
2020 \text { [130] }\end{array}$ & $12,667 \mathrm{MP} / \mathrm{m}^{3}$ & $\begin{array}{c}12667 \pm 668 \\
3514 \pm 543 \text { and } 423 \pm \\
44.9 \mathrm{MP} / \mathrm{m}^{3}\end{array}$ & $37-500 \mu \mathrm{m}$ & n.a & $96.7 \%$ & $\begin{array}{c}\text { Visual } \\
\text { Observation and } \\
\text { Micro-Raman } \\
\text { spectrometry }\end{array}$ & $\begin{array}{l}\text { Iran } \\
\text { (Sari) }\end{array}$ \\
\hline $\begin{array}{c}\text { Edo et al, } 2020 \\
{[109]}\end{array}$ & n.a & $12.8 \pm 6.3 \mathrm{MP} / \mathrm{L}$ & 25 to $104 \mu \mathrm{m}$ & $\begin{array}{c}\text { Primary } \\
\text { and secondary }\end{array}$ & $>90 \%$ & $\begin{array}{l}\text { Visual inspection } \\
\text { and FT-IR }\end{array}$ & $\begin{array}{c}\text { Spain } \\
\text { (Madrid) }\end{array}$ \\
\hline $\begin{array}{l}\text { Ben-David et al., } \\
\quad 2021[131]\end{array}$ & $28.28 \mathrm{MP} / \mathrm{L}$ & $1.97 \mathrm{MP} / \mathrm{L}$ & $\geq 20 \mu \mathrm{m}$ & $\begin{array}{l}\text { Primary, } \\
\text { Secondary and } \\
\text { tertiary }\end{array}$ & $97 \%$ & $\begin{array}{c}\text { optical } \\
\text { microscopy, } \\
\text { SEM and } \\
\mu \text {-Raman } \\
\text { microscopy }\end{array}$ & $\begin{array}{c}\text { Israel } \\
\text { (Karmiel) }\end{array}$ \\
\hline $\begin{array}{c}\text { Tagg et al., } 2020 \\
{[117]}\end{array}$ & n.a & $1.5 \mathrm{MP} / \mathrm{L}$ & $392 \mu \mathrm{m}$ & $\begin{array}{l}\text { Primary, } \\
\text { Secondary } \\
\text { and tertiary }\end{array}$ & $76.9 \%$ & micro-FT-IR & $\begin{array}{c}\text { UK } \\
\text { (East } \\
\text { Midlands) }\end{array}$ \\
\hline $\begin{array}{c}\text { Akarsu et al., } 2020 \\
\text { [132] }\end{array}$ & 1.1 and $3.6 \mathrm{MP} / \mathrm{L}$ & $0.9 \mathrm{MP} / \mathrm{L}$ & 1057 and 1095 & $\begin{array}{l}\text { Primary, } \\
\text { Secondary } \\
\text { and tertiary }\end{array}$ & $55 \%-97 \%$ & FT-IR & $\begin{array}{c}\text { Turkey } \\
\text { Mersin Bay }\end{array}$ \\
\hline $\begin{array}{c}\text { Bayo et al., } 2020 \\
{[110]}\end{array}$ & $15.70 \mathrm{MP} / \mathrm{L}$ & 13.04 MP/L & 400 to $600 \mu \mathrm{m}$ & Primary & $90.3 \%$ & $\begin{array}{l}\text { Visual inspection } \\
\text { and FT-IR }\end{array}$ & $\begin{array}{c}\text { Spain } \\
\text { (Cartagena) }\end{array}$ \\
\hline $\begin{array}{c}\text { Naji et al., } 2021 \\
{[133]}\end{array}$ & $\begin{array}{c}74( \pm 11.01, S D) \\
\text { and } 67( \pm 18.35 \\
\text { SD) MP } 35 / \mathrm{L}\end{array}$ & $70.66 \mathrm{MP} / \mathrm{L}$ & $>250 \mathrm{~mm}$ & $\begin{array}{c}\text { Primary and } \\
\text { secondary }\end{array}$ & n.a & $\begin{array}{l}\text { SEM and X-ray } \\
\text { EDX }\end{array}$ & $\begin{array}{c}\text { Iran } \\
\text { (Bandar } \\
\text { Abbas City) }\end{array}$ \\
\hline $\begin{array}{c}\text { Tang et al., } 2021 \\
{[136]}\end{array}$ & $\begin{array}{c}23.3 \mathrm{MP} / \mathrm{L} \text { and } \\
80.5 \mathrm{MP} / \mathrm{L}\end{array}$ & 23.3 to $7.9 \mathrm{MP} / \mathrm{L}$ & 0.636 to 0.803 & $\begin{array}{l}\text { Primary and } \\
\text { secondary }\end{array}$ & $\begin{array}{l}66.1 \% \text { and } \\
62.7 \%\end{array}$ & $\begin{array}{c}\text { Raman } \\
\text { spectroscopy }\end{array}$ & $\begin{array}{c}\text { China } \\
\text { (Wuhan City) }\end{array}$ \\
\hline $\begin{array}{c}\text { Park et al., } 2020 \\
\text { [137] }\end{array}$ & 10 to $470 \mathrm{MP} / \mathrm{L}$ & 10 to $470 \mathrm{MP} / \mathrm{L}$ & $45 \mu \mathrm{m}$ to $5 \mathrm{~mm}$ & $\begin{array}{l}\text { Primary, } \\
\text { Secondary } \\
\text { and tertiary }\end{array}$ & $\begin{array}{l}98.7 \%- \\
99.99 \%\end{array}$ & FT-IR & Korea \\
\hline $\begin{array}{c}\text { Rajala et al., } 2020 \\
\text { [138] }\end{array}$ & n.a & $\begin{array}{c}0.1 \mathrm{mg} / \mathrm{L}, 6.7 \mathrm{mg} / \mathrm{L} \\
\text { (used) }\end{array}$ & $1 \mu \mathrm{m}$ and $6.3 \mu \mathrm{m}$ & Secondary & $99.4 \%$ & $\begin{array}{l}\text { coagulation/ } \\
\text { flocculation }\end{array}$ & Finland \\
\hline $\begin{array}{l}\text { Nguyen et al., } \\
2021 \text { [139] }\end{array}$ & n.a & n.a & $>45 \mu \mathrm{m}$ & $\begin{array}{l}\text { Primary, } \\
\text { Secondary and } \\
\text { tertiary }\end{array}$ & $80 \%$ & $\begin{array}{c}\text { Microscopic and } \\
\text { FT-IR }\end{array}$ & $\begin{array}{l}\text { Korea } \\
\text { (Seoul) }\end{array}$ \\
\hline $\begin{array}{c}\text { Alvim et al., } 2020 \\
{[140]}\end{array}$ & n.a & $11.1 \mathrm{MP} / \mathrm{L}$ & $<1 \mathrm{~mm}$ & $\begin{array}{l}\text { Primary, } \\
\text { Secondary }\end{array}$ & n.a & $\begin{array}{c}\text { Visual/ } \\
\mu \text {-ATR-FTIR }\end{array}$ & $\begin{array}{c}\text { Spain } \\
\text { (Valencia) }\end{array}$ \\
\hline $\begin{array}{c}\text { Yuan et al., } 2020 \\
\text { [141] }\end{array}$ & n.a & $10.30 \mathrm{MP} / \mathrm{L}, 6.10 \mathrm{MP} / \mathrm{L}$ & 141 to $665 \mu \mathrm{m}$ & $\begin{array}{l}\text { Primary, } \\
\text { Secondary and } \\
\text { tertiary }\end{array}$ & $\begin{array}{c}97.67 \% \text { and } \\
98.46 \%\end{array}$ & n.a & $\begin{array}{c}\text { China } \\
\text { (Nanjing) }\end{array}$ \\
\hline $\begin{array}{c}\text { Pittura et al., } 2021 \text { ( } \\
\text { [142] }\end{array}$ & $\begin{array}{c}(12,170,000 \mathrm{MP} / \mathrm{h}) \\
3.6 \mathrm{MP} / \mathrm{L}\end{array}$ & $1,730,000 \mathrm{MP} / \mathrm{h}$ & $<1 \mathrm{~mm}$ & $\begin{array}{l}\text { Primary, } \\
\text { Secondary }\end{array}$ & $94 \%$ & $\begin{array}{c}\text { Stereomicroscope } \\
\text { and } \mu \text { FT-IR }\end{array}$ & Italy \\
\hline $\begin{array}{c}\text { Zou et al., } 2020 \text { al. } \\
\text { [143] }\end{array}$ & n.a & $1.719 \pm 1.035 \mathrm{MP} / \mathrm{L}$ & n.a & n.a & n.a & n.a & $\begin{array}{c}\text { China } \\
\text { (Guangzhou) }\end{array}$ \\
\hline $\begin{array}{c}\text { Mak et al., } 2020 \\
{[134]}\end{array}$ & n.a & $10,816 \mathrm{MP} / \mathrm{m}^{3}$ & 90 to $189 \mu \mathrm{m}$ & $\begin{array}{l}\text { Primary, } \\
\text { Secondary }\end{array}$ & $86.4 \%$ & & $\begin{array}{l}\text { Hong Kong } \\
\text { (Victoria } \\
\text { Harbor) }\end{array}$ \\
\hline
\end{tabular}




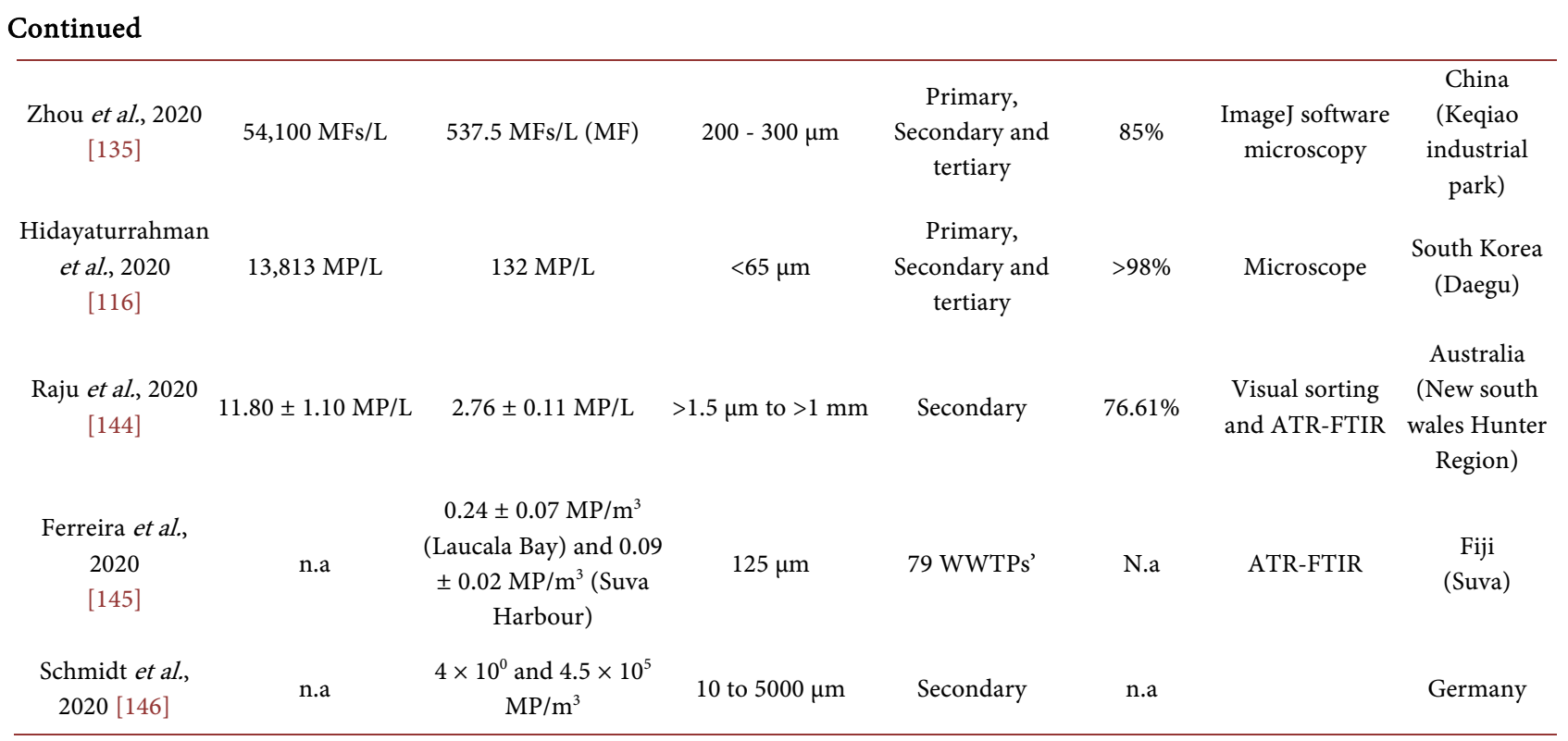
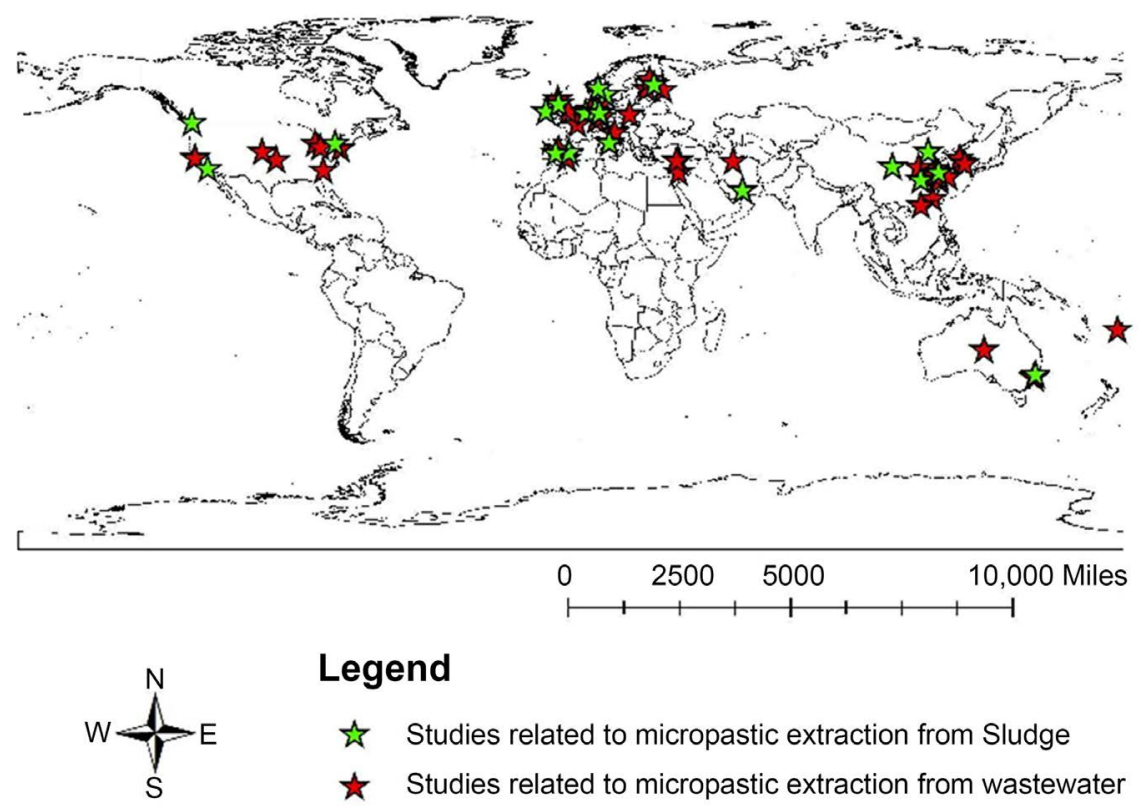

Figure 3. World map showing the locations of the studies carried out on MP in WWTPs (Table 1 and Table 2).

the use of extraction pumps [83] [92] [97] [98] [99], the use of neuston/plankton nets [99] [118] to analysing composite samples [83] [91] [97] [106] [112]. From wastewater, microplastics can be separated by visual selection, but can also be detected by spectroscopic imaging such as by focal plane array (FPA)-based micro-Fourier transform infrared (micro-FTIR) imaging [94] [147] [148] [149] after filtration onto a membrane filter. Micro- and nanoplastics, while having been studied by the use of scanning electron microscopy, X-ray photoelectron spectroscopy (SEM-XPS), can also be identified by micro-Raman imaging techniques [56] [150] [151]. Wastewater is a biogenic organic matter-rich matrix, which 
makes MP detection, isolation and quantification difficult [117]. There are but few studies that address the MP flux through a WWTP over a long period of time [91] [111]. Additionally, most studies have solely looked at MP concentrations in the WWTP influent and final effluent, but only few studies have investigated the MP concentrations at the different treatment stages [90] [117]. Nanoplastics (NPs) have also not been assessed thoroughly.

Figure 2, possible set-up of a wastewater treatment plant (partially adopted from [142]).

Nevertheless, it is clear that WWTPs cannot completely retain MPs, and that the effluent from WWTPs contributes to the MP load in receiving waters [83] [90] [93] [95] [99] [101] [102] [113] [114] [152]. In many cases, there is a significantly higher concentration of MPs downstream of a WWTP as compared to upstream [89] [153]. MPs ranging in size from 20 to $1000 \mu \mathrm{m}$ have been found in WWTP effluents [16], in amounts of between $9.3 \times 10^{5}$ to $4.0 \times 10^{9}$ particles per day [16]. Many WWTPs also receive stormwater run-off, which can be discharged in cases of severe weather after only basic physicochemical treatment or with no treatment at all, and in such cases larger amounts of MPs can be released from WWTPs into the environment [154]. Nevertheless, there is still a high uncertainty in regard to overall MP emissions from WWTPs [44] [47] [96] [113] [153]. It has been noted, however, that there is a greater chance of smaller microplastics to break through WWTPs [101].

An important variable in the MP emission to the environment is the nature of the tertiary stage of the WWTP that can include advanced separation methods such as ultrafiltration and reverse osmosis. Rapid sand filters (RSF) [110] can remove up to $97 \%$ of microplastics from the effluent of a secondary stage of a WWTP. As part of the last stage of a tertiary WWTP, they are deemed to be economical and can be operated at a reasonable scale [114]. However, microplastics between $0.02 \mu \mathrm{m}$ and $2 \mu \mathrm{m}$ in size have been reported to travel through sand [155]. In this regard, spherical microbeads have the highest mobility through sandfilters as compared to fibers, microplastic fragments, microtyres and plastic films, and it has been shown that in certain locations these microbeads constitute the largest portion of microplastics released with the effluent of tertiary WWTPs [116]. Nevertheless, also small fibers have been reported to travel through RSFs, where in one study the removal efficiency for small fibers by RSF was only $53.8 \%$. Also, sand filtration has been noted to fragment microplastics into even smaller particles [4] [114]. Ultrafiltration (UF) is often used for the removal of particulates and macromolecules from raw water to produce potable water, and is more and more replacing secondary treatment methods such as coagulation, flocculation, and sedimentation and more classical tertiary filtration such as sand filtration. While UF, typically having polymeric or ceramic membranes with a pore size between $1-100 \mathrm{~nm}$, is laid out to retain large organic molecules such as proteins as well as bacteria, protozoa, and viruses, UF is not specifically designed to retain micro- or nanoplastics [156]. Often- 
times, pre-treatments are necessary for the successful use of UF as UF membranes can be fouled easily. To that effect, a coagulation step as pretreatment with iron-based coagulants has been advocated, especially in combination with an addition of polyacrylamide (PAM), which increased the removal efficiency of small-sized polyethene particles $(\mathrm{d}<0.5 \mathrm{~mm})$ significantly from $13 \%$ to $91 \%$ [157] [158].

Membrane bioreactors, in which the action of biological catalysts (bacteria, enzymes), is coupled to a separation process have been seen to remove $99.9 \%$ of MPs (from 6.9 to $0.005 \mathrm{MP} \cdot \mathrm{L}^{-1}$ ), while disc filters have a removal efficiency of $40 \%-98.5 \%$ (from 0.5 - 2.0 to $0.03-0.3 \mathrm{MP} \cdot \mathrm{L}^{-1}$ ) [114]. However, fouling also of MBRs through MPs has been noted, where PVC MPs artificially added at a concentration of $10 \mathrm{MPs} / \mathrm{L}$ inhibited the removal performance of the MBR towards polluting organic matter and ammonia [159]. Also, the process is quite expensive, both in investment (membrane) as well as in running costs (high energy consumption) [3] [4].

S. Fortin [151] has compared the efficiency of two other advanced tertiary treatment methods, namely of reverse osmosis nanofiltration and of activated carbon filtration systems, where in a pilot program was fed secondary effluent water with return activated sludge added to it to increase the turbidity. This water was branched and fed into the two different advanced treatment methods. The carbon train system was composed of a flocculation/sedimentation step followed by an ozonation step and treatment with bacterial activated carbon and granular activated carbon columns, before undergoing UVD/UVA disinfection. The other train consisted of a reverse osmosis nano-filtration step followed by UVD/UVA disinfection [151]. It was found that the reverse osmosis nano-filtration produced effluent that still showed microplastics with a relatively narrow size distribution of $1 \mu \mathrm{m}$ and $10 \mu \mathrm{m}$, though over $90 \%$ of the particles were smaller than $10 \mu \mathrm{m}$, while the filtration on activated carbon gave effluent with much larger particles remaining, with $54 \%$ of the total particles larger than $10 \mu \mathrm{m}$. Many of the particles were not plastic but inorganic particles, some stemming from a prior flocculation step. Overall, the study found more small microparticles than previous studies have had, most likely due to a better quantification of the microparticles by Raman microspectroscopy [151]. All of the membrane processes above are of interest and continue to be developed. In order to be commercially viable, especially for larger WWTPs, the methods need to be cost-effective and have a high through-put.

\subsection{Microplastics in Sludge}

As much of the retained MP material (about $90 \%$ on the average) ends up in the sludge of WWTPs [14], high concentrations of MPs in WWTP sludge samples have been described in many studies [47] [76] [96] [98] [160] [161] [162]. Mahon et al. [161] found microplastic in concentrations of 4.20 to $15.4 \times 10^{3}$ particles $\mathrm{kg}^{-1}$ dry sludge. Lassen et al. [47] reported that sludge samples from Ger- 
man WWTPs contain 1.00 to $24.0 \times 10^{3} \mathrm{MP}$ particles $(10 \mathrm{~mm})$ per $\mathrm{kg}$ of dry sludge. A comparison of MP concentrations in sludge collected at different WWTPs from around the world is given in Table 2. Sludge from 8 WWTPs in Norway (Oslo, Stavanger, Tromsø, Federickstand, among others), serving altogether 1,500,000 inhabitants and producing about 100,000 tons of sludge, revealed an overall average plastic abundance of 6077 particles $\mathrm{kg}^{-1}(\mathrm{dw})$, of which $37.6 \%$ were beads, $31.8 \%$ fragments, and $28.9 \%$ fibers. The most common constituents were found to be polyethylene (PE, 30.5\%), polyethylene terephthalate (PET, 26.7\%) and polypropylene (PP, 20.3\%) [163]. Sujathan et al. reported a very high microplastic particle count of $4.95 \times 10^{5}$ per $\mathrm{kg}(\mathrm{dw})$ in return activated sludge [164]. In the study, microplastics as small as $0.48 \mu \mathrm{m}$ could be identified, which may mean that many microplastic particles in WWTP sludge are indeed small and escape detection [163].

Table 2. Studies on microplastics (MP) in accumulated sludge from wastewater treatment plants (WWTPs).

\begin{tabular}{|c|c|c|c|c|c|}
\hline Type of WWTP's & Country & MP size range & $\begin{array}{l}\text { MP concentration (particles } \\
\mathrm{kg}^{-1} \text { d.w. }{ }^{\mathrm{a}} \text { and } \mathrm{w} \cdot \mathrm{w}^{\mathrm{b}} \text { ) }\end{array}$ & Analytical Method & References \\
\hline (7WWTPs,) & $\begin{array}{c}\text { Ireland } \\
\text { (7WWTPs) }\end{array}$ & $250 \mu \mathrm{m}-4 \mathrm{~mm}$ & $4196-15,385$ & Optical and FT-IR & $\begin{array}{c}\text { Mahon et al., } 2017 \\
{[161]}\end{array}$ \\
\hline (7WWTPs,) & $\begin{array}{l}\text { Netherlands } \\
\text { (Amsterdam) }\end{array}$ & $0.7 \mu \mathrm{m}-5 \mathrm{~mm}$ & $370-950$ & FT-IR & Leslie et al., [104] \\
\hline n.a & $\begin{array}{l}\text { Sweden } \\
\text { (Lysekil) }\end{array}$ & $300 \mu \mathrm{m}-5 \mathrm{~mm}$ & $16.7^{\mathrm{a}} \times 10^{4}$ & FT-IR & $\begin{array}{c}\text { Magnusson \& Norén, } \\
2014[96]\end{array}$ \\
\hline n.a & $\begin{array}{c}\text { (USA) } \\
\text { Ithaca, New York }\end{array}$ & No Data & About $1000-4000$ & Filtration techniques & $\begin{array}{l}\text { Zubris and Richards, } \\
2017 \text { [165] }\end{array}$ \\
\hline \multirow[t]{2}{*}{$\begin{array}{c}\text { Primary, Secondary } \\
\text { and Tertiary }\end{array}$} & $\begin{array}{c}\text { USA } \\
\text { (Los Angeles County) }\end{array}$ & $<5 \mathrm{~mm}$ & 5000 & $\begin{array}{l}\text { Visual sorting, } \\
\text { Microscope FT-IR }\end{array}$ & Carr et al., 2016 [99] \\
\hline & $\begin{array}{c}\text { China } \\
\text { (28WWTPs,) }\end{array}$ & $37 \mu \mathrm{m}-5 \mathrm{~mm}$ & $1565-56,386^{\mathrm{a}}$ & & Li et al., 2018 [166] \\
\hline \multirow[t]{2}{*}{$\begin{array}{l}12 \text { WWTPs: } \\
\text { mostly secondary } \\
\text { and tertiary }\end{array}$} & $\begin{array}{l}\text { Germany } \\
\text { (Oldenburg }\end{array}$ & $<5 \mathrm{~mm}$ & 1000 to $24,000^{\mathrm{a}}$ & micro-FT-IR & $\begin{array}{c}\text { Mintening et al., 2014, } \\
2017 \text { [94] [101] }\end{array}$ \\
\hline & $\begin{array}{l}\text { Germany } \\
\text { (Seelze) }\end{array}$ & 20 to $100 \mu \mathrm{m}$ & $495,000^{\mathrm{a}}$ & confocal Raman microscopy & $\begin{array}{l}\text { Sujathan et al., } 2017 \\
\text { [164] }\end{array}$ \\
\hline Secondary & $\begin{array}{c}\text { UK } \\
\text { (Glasgow) }\end{array}$ & $1.34-1.62 \mathrm{~mm}$ & About $2000^{\mathrm{b}}$ & FT-IR & $\begin{array}{c}\text { Murphy et al., } 2016 \\
{[90]}\end{array}$ \\
\hline $\begin{array}{c}\text { Primary } \\
\text { and secondary }\end{array}$ & $\begin{array}{l}\text { Finland } \\
\text { (Mikkeli) }\end{array}$ & $<1 \mathrm{~mm}$ & $8.2-301.4^{\mathrm{b}}$ & FT-IR and Raman Microscope & Lares et al., 2018 [95] \\
\hline \multirow[t]{2}{*}{$\begin{array}{c}\text { Primary } \\
\text { and secondary }\end{array}$} & $\begin{array}{c}\text { Canada } \\
\text { (Vancouver) }\end{array}$ & $64 \mu \mathrm{m}$ & $4400^{\mathrm{b}}$ & Microscopy and FT-IR & Gies et al., 2018 [119] \\
\hline & $\begin{array}{c}\text { Norway } \\
(10 \text { WWTPs })\end{array}$ & $54 \mu \mathrm{m}$ to $5 \mathrm{~mm}$ & $6077^{\mathrm{a}}$ & $\mu$-FT-IR & $\begin{array}{c}\text { Lusher et al., } 2018 \\
\text { [163] }\end{array}$ \\
\hline n.a & $\begin{array}{l}\text { China } \\
\text { (Jiangsu) }\end{array}$ & 25 to $>500 \mu \mathrm{m}$ & 1.6 and $0.7^{\mathrm{b}}$ & FT-IR & $\begin{array}{c}\text { Lv et al., } 2019 \\
{[125]}\end{array}$ \\
\hline $\begin{array}{c}\text { Primary } \\
\text { and secondary }\end{array}$ & $\begin{array}{c}\text { China } \\
\text { (Wuhan) }\end{array}$ & 100 to $800 \mu \mathrm{m}$ & $24,030^{\mathrm{a}}$ & Visual inspection and FT-IR & $\begin{array}{c}\text { Liu et al., } 2019 \\
{[126]}\end{array}$ \\
\hline
\end{tabular}




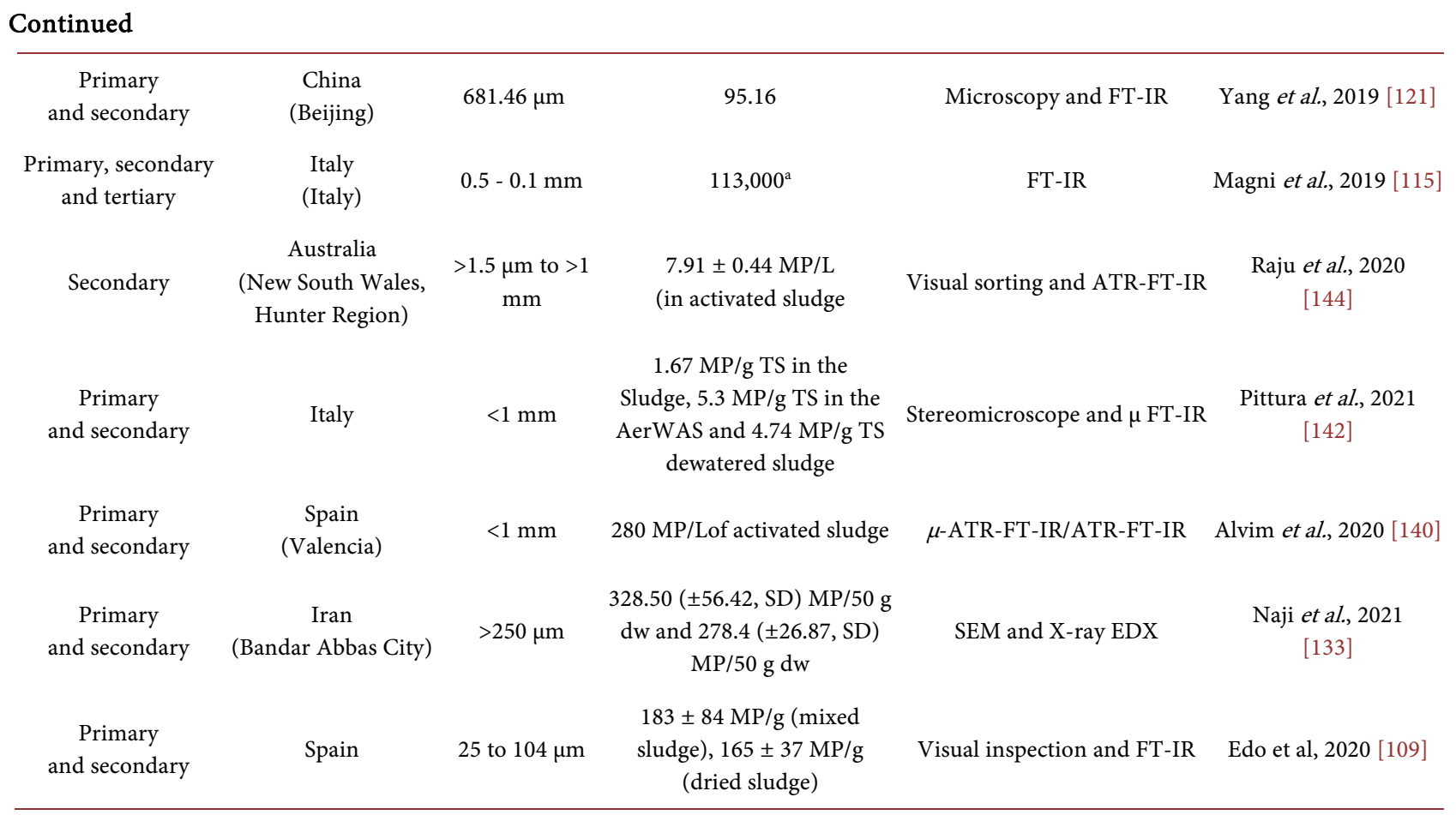

The site map of Figure 3 shows the locations of the studies on a world map. ${ }^{\mathrm{a} D M}$, dry matter. ${ }^{\mathrm{b}}$ The unit is particles $\mathrm{kg}^{-1}$ wet weight and the dry weights of the wet sewage sludge samples were all below $1 \%$.

Oftentimes, sludge after thickening, is treated in a thermal hydrolysis reactor and then goes into an anaerobic digester. Afterwards, the sludge is dried. It must be noted that while sewage sludge is added to soil, smaller amounts of sludge can also be incinerated. The latter might also be added to a landfill. Also, an appreciable quantity [90] [114] [167] of microplastics, especially those of low density such as LDPE and PP, can be separated off in the primary steps of the wastewater treatment, in grit traps and during grease skimming. These separated wastes are usually put into landfills or are incinerated [99] [163].

The application of sludge to agricultural soils and municipal green areas as well as its use by soil producers raises the concentration of microplastics in soils significantly [168] [169] [170]. In addition, microplastics are entering soil via plastic mulching, irrigation with grey water, and through run-offs. Also, air movement contributes to the dissemination of microplastics in farming areas [91] [171]. The occurrence and fate of microplastics in soil are less studied [172] [173] [174] [175] [176] than of microplastics in the marine environment. It has been calculated that in Norway alone, 500 billion $\left(5 \times 10^{11}\right)$ pieces of microplastic find their way into the soil via sewage sludge applied to agricultural soils [163]. This compares with an estimated $1.56 \times 10^{14}$ plastic particles per year entering Chinese soil [166], and 300,000 and 430,000 tons/year of plastic distributed over European and North American agricultural land [73] [172]. While plastics structurally weather under the influence of humidity, temperature, UV-radiation and wind [173], they remain chemically intact in the soil for long periods of time [177], with slow chemical oxidation and UV driven bond scis- 
sion being the two main degradation mechanisms reported [178].

As stated above, in WWTPs, sludge undergoes prior steps before being released such as thickening and final dewatering, which can involve a centrifugation step. Oftentimes, digestion steps are incorporated in the treatment. These can be anaerobic digestion or aerobic digestion/composting. Here, L. Pittura et al. have shown that $86 \%$ of MPs (which included $100 \%$ of the particles and $87 \%$ of the fibers) can be retained with a pilot scale upflow granular anaerobic sludge blanket (UASB) in combination with an anaerobic membrane bioreactor (AnMBr) [142]. However, MPs can have potential adverse effects on anaerobic processes, which normally yield biogas as a useful side-product. Thus, L. Pittura et al. [142] have shown that in their case the presence 50 polypropylene MPs per $\mathrm{g}$ of solid led to a decrease of the methanogenic activity by $58 \%$. This "poisoning" of the anaerobic microorganisms may be due to leachates from the MPs, which contain small organic molecules but also heavy metals. The organic molecules can stem from plastic additives to MPs such as added plasticizers, antioxidants or UV absorbents or they themselves could have been adsorbed to the MPs at some point in their history and are now released. Also, other research groups have commented on this inhibition of methanogenic activity by MPs (and NPs) in lab scale anaerobic digestion processes of wastewater or simulated wastewater and in lab scale UASB processes [179] [180] [181] [182] [183]. PE-MPs [180], PEST-MPs [179], PET-MPs [182], PS-MPs [183], and PVC-MPs [181] all showed this inhibition.

It has been shown that a fraction of up to $20 \%$ the microplastic can be recycled back into the reject water during the sludge dewatering step [114] and thus will cycle through the system on more time. The fate of microplastics in thermal treatment processes such as in the Cambi process (i.e., at $160^{\circ} \mathrm{C}$ ) or incineration processes has not been studied in detail. Mahon et al. have described a potential shredding of MPs in lime stabilization processes, leading to smaller sized MPs. MPs having gone through the sludge thermal drying process showed signs of melting and blistering [161]. We have noted that some plastic microbeads contained in personal care products undergo fragmentation when cycled on silica gel from room temperature to $100^{\circ} \mathrm{C}$ and back to $\mathrm{rt}$ [17]. Synthetic fibers, which are more ubiquitous, are usually more indestructible. Rom et al. have looked at polylactide microfibers and have found that they were not biodegraded by treatment with activated sludge under mesophilic $\left(36^{\circ} \mathrm{C}\right)$ or thermophilic $\left(56^{\circ} \mathrm{C}\right)$ conditions, even after 4 weeks [184].

\section{Laboratory-Scale Development of New Methods for the Removal of Micro- and Nanoplastics from Aqueous Systems Suitable for Implementation in Wastewater Treatment}

There are a number of new methods under development for the removal of micro- and nanoparticles that can be deemed suitable for implementation at a future time. Mainly, they are based on adsorption [185] [186] [187], coagulation 
techniques [157] [158] [188]-[194] and membrane filtration [156]. This becomes important also in regard to eliminating microplastics (and potentially nanoplastics) from drinking water derived from drinking water treatment plants (DWTPs) [195] [197] [198], where MP have been found not only in the ground water used by DWTPs, but also in tap water [199] and bottled mineral water [200] [201] [202]. Kosuth et al. have found MP in $81 \%$ of 156 drinking water samples collected from 14 countries [203].

First, we turn to adsorption or other types of retention of MPs on different materials leading to different filtrations. Z. Wang et al. have looked at replacing sand filters with biochar filters [187]. The filters were either comprised of corn straw biochar produced at $500{ }^{\circ} \mathrm{C}$ or of commercially available hardwood biochar. Leachate column tests were performed with spherical $10 \mu \mathrm{m}$ polystyrene beads at a concentration of $1.6 \times 108$ suspended beads/L distilled water. The removal efficiency of such filters was found to be more than 95\% [187]. C. Sun et al. have developed artificial sponges made from chitin and graphene oxide cross-linked with the help of epichlorohydrin, which were found to take up polystyrene, carboxylate modified polystyrene and amine-modified polystyrene microbeads of $1 \mu \mathrm{m}$ size with maximum adsorption capacities of 5.99. 7.53 and $8.46 \mathrm{mg} / \mathrm{g}$, respectively [186]. The sponges could be reused, although the regeneration of the sponges involves a complex process of rinsing with larger amounts of ethanol, cooling them down to $-80^{\circ} \mathrm{C}$ for $4 \mathrm{~h}$ and freeze-drying [186].

Looking at chemical coagulation-flocculation processes, G. Zhou et al. [190] used polyaluminium chloride (PAC) and ferric chloride $\left(\mathrm{FeCl}_{3}\right)$ as coagulants for $\mathrm{PE}$ and PS microplastics, finding 77.8\% (PS) and 29.7\% (PE) removal efficiencies with $\mathrm{PAC}$ and $64 \%$ (PS) and 17.4\% (PE removal efficiencies with $\mathrm{FeCl}_{3}$. Interestingly, with these systems the smaller sized PE microplastics could be removed more efficiently, while for PS it was just the reverse [190]. N. Shahi et al. have turned to using alum coagulant alone or in combination with polyamine-coated (PC) sand. Here, a combination of PC sand $\left(500 \mathrm{mg} \cdot \mathrm{L}^{-1}\right)$ with alum $\left(20 \mathrm{mg} \cdot \mathrm{L}^{-1}\right)$ gave an MP removal of $97 \%$ for PE-MPs, where it was noted that size, shape and surface morphology plays a significant role in the coagulation and flocculation processes [192]. K. Rajala et al. [138] have studied the effectiveness of PAC and $\mathrm{FeCl}_{3}$ in MP removal by artificially adding PS microspheres, 1 and $6.3 \mu \mathrm{m}$ in size, respectively, to a WW matrix stemming from the effluent of a secondary WWTP in Finland. M. Lapointe et al. [194] looked at the difference in coagulation and flocculation behaviour of pristine and weathered microplastics, using polyethene microspheres ( $15 \mu \mathrm{m}$ and $140 \mu \mathrm{m}$ in size), polystyrene microspheres $(140 \mu \mathrm{m}$ in size) and polyester fibers (12 - $16 \mu \mathrm{m}$ wide, $105-1325 \mu \mathrm{m}$ long). Alum (0.45 $3.64 \mathrm{mg} \mathrm{Al} / \mathrm{L}$ ) and polyacrylamide (PAM, $0.05-0.30 \mathrm{mg} / \mathrm{L}$ ) were used as coagulant/flocculant. It was seen that polyester fibers were removed more efficiently (99\%) than the microbeads (82\% - 84\%). Again, smaller sized microbeads were removed more facilely than larger ones. Weathered (aged) PE microbeads were more easily removed than pristine beads. The authors rationalized this behaviour 
with the slow oxidation of the PE bead surface which allows such functionalities as $-\mathrm{OH},-\mathrm{CO}_{2} \mathrm{H}$, and $-\mathrm{C}=\mathrm{C}$ - to form. With a quartz crystal microbalance, the deposition of coagulant and flocculant was investigated on a plastic surface. Here, it was seen that cationic PAM showed the highest deposition rate. Z. Chen et al. [204] have demonstrated an interesting flocculation method for the removal of NPs with different salt-based flocculants, which not only included aluminium but also calcium. Calcium ions show an excellent sedimentation performance for impurities at high $\mathrm{pH}$. It has been described that flocculation occurring between composite metal calcium-aluminium $(\mathrm{Ca} / \mathrm{Al})$ ions and nanoplastics showed the best performance, again at high $\mathrm{pH}$ [204]. As many synthetic polymers used as flocculants exhibit some toxicity, especially due to small concentrations of monomers in the materials, bio-based polymeric flocculants have been suggested [205]. Here, the problem is their poor water solubility and their low charge density [206] [207]. Nevertheless, S. Magalhães et al. have performed initial experiments using a cationic hydrophobically modified cellulose derivative as a bio-flocculant for the flocculation PET microplastics [206].

Electrocoagulation uses sacrificial iron or aluminium electrodes and usually forms iron- and aluminium hydroxides as coagulant material. As with the addition of chemical coagulants, these destabilize the surface charges on the surface of the suspended solids. The suspension is broken up, and the particles, approaching each other more closely, interact by van der Waals forces to form a conglomerate of particles. The hydrogen liberated during the electrolysis process lifts these larger conglomerates together with the blanketing coagulant to the water surface. In their set-up, W. Perren et al. [189] used seven metal electrodes, one as cathode, one as working anode and the five remaining as sacrificial anodes. The added spherical polyethene beads of $300-355 \mu \mathrm{m}$ size were found to aggregate on the positive electrode faces. The microplastic particles underwent simultaneous charge neutralisation and flocculation to create a stable floc on the water's surface. A minimum of $2 \mathrm{~g} / \mathrm{L} \mathrm{NaCl}$ salt concentration was employed. The microbead removal efficiency increased with increasing salt concentration [189].

It was seen that mesoparticles (i.e., $20 \mu \mathrm{m}-0.5 \mu \mathrm{m}$, falling within the size of many microplastics) can play a role in irreversible membrane fouling and that a prior coagulation process is of utmost importance [208]. An alternative membrane separation technology is that using dynamic membranes (DMs). DMs operate with a layer produced on a supporting membrane by particles in the influent. So, these particles in the influent form a filtration layer that can be supported by a larger pore-sized mesh or by low-cost porous materials. DMs have been run successfully with particles that are of a similar size to microplastics [209]. Also membranes made from electrospun lignin-zeolite composite nanofibers, with $1 \mathrm{wt} \%$ zeolite, were found to retain polystyrene microbeads of size $>1$ $\mu \mathrm{m}(\mathrm{R}=94.7 \%)$ after five cycles of filtration [210]. Zirconium based metal organic frameworks (MOFs) in form of foams have been utilized as filters. They are recyclable and operate at a MP removal efficiency of up to $95.5 \%$. A large 
scale filtration with these materials as filters was carried out [211].

The following shows some further intriguing approaches for the removal of MPs from wastewater, but they may be less suitable for a high through-put WWTPs and more suitable for batch treatments. One such approach centres on centres on the adsorption of nanoparticles on MPs that induce a property change in the MPs such as a change in density or giving the composite magnetic properties. Also, the use of hydrophobic magnetic nanoparticles has been forwarded. One such method uses magnetic polyoxometalate supported ionic liquid phases (magPOM-SILPs), in which magnetic iron oxide/silica core-shell precursor particles, with an average size of $16 \mathrm{~nm}$, are treated with a polyoxometalate ionic liquid $\left.\left(\mathrm{n}-\mathrm{C}_{7} \mathrm{H}_{15}\right)_{4} \mathrm{~N}^{+}\right)_{8}\left[\alpha-\mathrm{SiW}_{11} \mathrm{O}_{39}\right]_{8}$-in acetone, giving a viscous coating to the particles. This makes the magPOM-SILPs attach themselves to the MPs. The mag-POM-SILPs with the attached MPs are then removed from the water with a permanent magnet [212]. The use of a coating of magnetic iron nanoparticles by reaction of the nanoparticles with hexadecyltrimethoxysilane (HDTMS) has also been reported to be suitable for the adsorption of MPs. Similar to the above, the nanoparticles with the attached MPS are removed from the water by a permanent magnet [213]. Lastly, an interesting approach to the removal of microparticles, incl. microplastics, in water is through their interaction with magnetic, self-moving microswimmers of the type Au@Ni@ $\mathrm{TiO}_{2}$, linked together in form of a chain. The microswimmers moving in a magnetic field have been used to clear water of the river Warnow in Germany from microparticles by "shoveling" or "pushing" interactions [214]. The microswimmers still lack selectivity to identify microplastics among other microparticles [214].

\section{Conclusion}

The emission of microplastics into the environment will be an ongoing problem for the foreseeable future. The phase-out of plastic microbeads in personal care products and of single use plastic in the food industry in certain regions is laudable, but will only have a limited impact on the continuous generation of polymeric microparticles that especially include synthetic fibers, microtires and secondary microplastics, incl. from plastic packaging. Therefore, WWTPs will play an ever-increasing role in frustrating the dispersal of these materials, specifically in the marine ecosystem. In this context, further research in four broader areas continues to be needed: 1) the creation of new techniques to better retain microparticles; 2) a more complete understanding of possible physiological effects of the materials in humans and animals; 3 ) the development of a more complete inventory of microplastic emissions; 4) a better knowledge of the fate and lifetime of microplastics in aquatic ecosystems and soil. This should go hand-in-hand with the development of new methods for the analysis of microand nanoplastics, also and especially in drinking water and food.

\section{Conflicts of Interest}

The authors declare no conflicts of interest regarding the publication of this paper. 


\section{References}

[1] Habib, R., Thiemann, T. and Al Kendi, R. (2020) Microplastics and Wastewater Treatment Plants. Journal of Water Resources and Protection, 12, 1-35. https://doi.org/10.4236/jwarp.2020.121001

[2] Uddin, S., Fowler, W. and Behbehani. M. (2020) An Assessment of Microplastic Inputs into the Aquatic Environment from Wastewater Streams. Marine Pollution Bulletin, 160, Article ID: 111538. https://doi.org/10.1016/j.marpolbul.2020.111538

[3] Cristaldi, A., Fiore, M., Zuccarello, P., Conti, G.O., Grasso, A., Nicolosi, I., Copat, C. and Ferrante, M. (2020) Efficiency of Wastewater Treatment Plants (WWTPs) for Microplastic Removal: A Systematic Review. International Journal of Environmental Research and Public Health, 17, 8014. https://doi.org/10.3390/ijerph17218014

[4] Sol, D., Laca, A., Laca, A. and Díaz, M. (2020) Approaching the Environmental Problem of Microplastics: Importance of WWTP Treatments. Science of the Total Environment, 740, Article ID: 140016. https://doi.org/10.1016/j.scitotenv.2020.140016

[5] Iyare, P.U., Ouki, S.K. and Bond, T (2020) Microplastics Removal in Wastewater Treatment Plants: A Critical Review. Environmental Science: Water Research \& Technology, 6, 2664-2675. https://doi.org/10.1039/D0EW00397B

[6] Bui, X.T., Vo, T.D.H., Nguyen, P.T., Nguyen, V.T., Dao, T.S. and Nguyen, P.D. (2020) Microplastics Pollution in Wastewater: Characteristics, Occurrence and Removal Technologies. Environmental Technology \& Innovation, 19, Article ID: 101013. https://doi.org/10.1016/j.eti.2020.101013

[7] Freeman, S., Booth, A.M., Sabbah, I., Tiller, R., Direking, J., Klun, K., Rotter, A., Ben-David, E., Javidpour, J. and Angel, D.L. (2020) Between Source and Sea: The Role of Wastewater Treatment in Reducing Marine Microplastics. Journal of Environmental Management, 266, Article ID: 110642. https://doi.org/10.1016/j.jenvman.2020.110642

[8] Zhang, Z.Q. and Chen, Y.G. (2020) Effects of Microplastics on Wastewater and Sewage Sludge Treatment and Their Removal: A Review. Chemical Engineering Journal, 382, Article ID: 122955. https://doi.org/10.1016/j.cej.2019.122955

[9] Ngo, P.L., Pramanik, B.K., Shah, K. and Roychand, R. (2020) Pathway, Classification and Removal Efficiency of Microplastics in Wastewater Treatment Plants. Environ. Pollution, 255, Article ID: 113326. https://doi.org/10.1016/j.envpol.2019.113326

[10] Zhang, X., Chen, J. and Li, J. (2020) The Removal of Microplastics in the Wastewater Treatment Process and Their Potential Impact on Anaerobic Digestion Due to Pollutants. Chemosphere, 251, Article ID: 126360. https://doi.org/10.1016/j.chemosphere.2020.126360

[11] Wu, M. Tang, W., Wu, S., Liu, H. and Yang, C. (2021) Fate and Effects of Microplastics in Wastewater Treatment Process. Science of the Total Environment, 757, Article ID: 143902. https://doi.org/10.1016/j.scitotenv.2020.143902

[12] Hu, Y., Gong, M.Y., Wang, J.Y. and Bassi, A. (2019) Current Research Trends on Microplastic Pollution from Wastewater Systems: A Critical Review. Reviews in Environmental Science and Biol Technology, 18, 207-230. https://doi.org/10.1007/s11157-019-09498-w

[13] Gatidou, G., Arvaniti, O.S. and Stasinakis, A.S. (2019) Review on the Occurrence and Fate of Microplastics in Sewage Treatment Plants. Journal of Hazardous Mate- 
rials, 367, 504-512. https://doi.org/10.1016/j.jhazmat.2018.12.081

[14] Sun, J., Dai, X.H., Wang, Q.L., van Loosdrecht, M.C.M. and Ni, B.J. (2019) Microplastics in Wastewater Treatment Plants: Detection, Occurrence and Removal. Water Research, 152, 21-37. https://doi.org/10.1016/j.watres.2018.12.050

[15] Raju, S., Carbery, M., Kuttykattil, A., Senathirajah, K., Subashchandrabose, S.R., Evans, G. and Thavamani, P. (2018) Transport and Fate of Microplastics in Wastewater Treatment Plants: Implications to Environmental Health. Reviews in Environmental Science and Bio/ Technology, 17, 637-653. https://doi.org/10.1007/s11157-018-9480-3

[16] Enfrin, M., Dumée, L. and Lee, J. (2019) Nano/Microplastics in Water and Wastewater Treatment Processes-Origin, Impact, and Potential Solutions. Water Research, 161, 621-638. https://doi.org/10.1016/j.watres.2019.06.049

[17] Habib, R.Z., Abdoon, M., Al Meqbaali, R., Ghebremedhin, F., Elkashlan, M., Kittaneh, W.F., Cherupurakal, N., Mourad, A.-H.I., Thiemann, T. and Al Kindi. R. (2020) Analysis of Microbeads in Cosmetic Products in the United Arab Emirates. Environmental Pollution, 258, Article ID: 113831. https://doi.org/10.1016/j.envpol.2019.113831

[18] Baensch-Baltruschat, B., Kocher, B., Stock, F. and Reifferscheid, G. (2020) Tyre and Road Wear Particles (TRWP)-A Review of Generation, Properties, Emissions, Human Health Risk, Ecotoxicity, and Fate in the Environment. Science of the Total Environment, 733, Article ID: 137823. https://doi.org/10.1016/j.scitotenv.2020.137823

[19] Kole, P.J., Löhr, A., Van Belleghem, F.G.A.J. and Ragas, A.M.J. (2017) Wear and Tear of Tyres: A Stealthy Source of Microplastics in the Environment. International Journal of Environmental Research and Public Health, 14, 1265-1296. https://doi.org/10.3390/ijerph14101265

[20] Cesa, F.S., Turra, A. and Baroque-Ramos, J. (2017) Synthetic Fibers as Microplastics in the Marine Environment: A Review from Textile Perspective with a Focus on Domestic Washings. Science of the Total Environment, 598, 1116-1129. https://doi.org/10.1016/j.scitotenv.2017.04.172

[21] Rathinamoorthy, R. and Balasaraswath, S.R. (2020) A Review of the Current Status of Microfiber Pollution Research in Textiles. International Journal of Clothing Science Technology. https://doi.org/10.1108/IJCST-04-2020-0051

[22] McDevitt, J.P., Criddle, C.S., Morse, M., Hale, R.C., Bott, C.B. and Rochman, C.M. (2017) Addressing the Issue of Microplastics in the Wake of the Microbead-Free Waters Act-A New Standard Can Facilitate Improved Policy. Environmental Science \& Technology, 51, 6611-6617. https://doi.org/10.1021/acs.est.6b05812

[23] United States (2015) Microbead-Free Waters Act of 2015. Pub.L. 114-114.

[24] Dauvergne, P. (2018) The Power of Environmental Norms: Marine Plastics: Pollution and the Politics of Microbeads. Environmental Politics, 27, 579-597. https://doi.org/10.1080/09644016.2018.1449090

[25] Nielsen, T.D., Holmberg, K. and Stripple, J. (2019) Need a Bag? A Review of Public Policies on Plastic Carrier bags-Where, How and to What Effect? Waste Management, 87, 428-440. https://doi.org/10.1016/j.wasman.2019.02.025

[26] Borkowski, K. (2019) Plastics Waste Litter in Oceans as a Driving Force for Regulations Plastics. Polimery, 64, 759-763. https://doi.org/10.14314/polimery.2019.11.4

[27] Andrady, A.L. (2011) Microplastics in the Marine Environment. Marine Pollution Bulletin, 62, 1596-1605. https://doi.org/10.1016/j.marpolbul.2011.05.030 
[28] Eerkes-Medrano, D., Thompson, R.C. and Aldridge, D.C. (2015) Microplastics in Freshwater Systems: A Review of Emerging Threats, Identification of Knowledge Gaps and Prioritization of Research Needs. Water Research, 75, 63-82. https://doi.org/10.1016/j.watres.2015.02.012

[29] Koelmans, A.A., Besseling, E. and Shim, W.J. (2015) Nanoplastics in the Aquatic Environment. In: Bergmann, M., Gutow, L. and Klages, M., Eds., Critical Review Marine Anthropogenic Litter, Springer International Publishing, Cham, 325-340. https://doi.org/10.1007/978-3-319-16510-3 12

[30] Cózar, A., Echevarría, F., González-Gordillo, J.L., Irigoien, X., Úbeda, B., Hernández-Leon, S., Palma, A.T., Navarro, S., Garcia-de-Lomas, J., Ruiz, A., Fernández-de-Puelles, M.L. and Duarte, C.M. (2014) Plastic Debris in the Open Ocean. Proceedings of the National Academy of Sciences of the United States of America, 111, 10239-10244. https://doi.org/10.1073/pnas.1314705111

[31] Ter Halle, A. Jeannau, L., Martignac, M., Jardé, E., Pedrono, B., Brach, L. and Gigault, J. (2017) Nanoplastic in the North Atlantic Subtropical Gyre. Environmental Science \& Technology, 51, 13689-13697. https://doi.org/10.1021/acs.est.7b03667

[32] Gigault, J., ter Halle, A., Baudrimont, M., Pascal, P.-Y., Gauffre, F., Phi, T.-L., El Hadri, H., Grassl, B. and Reynaud, S. (2018) Current Opinion: What Is a Nanoplastic? Environmental Pollution, 235, 1030-1034. https://doi.org/10.1016/j.envpol.2018.01.024

[33] Bondelind, M., Nguyen, A., Sokolova, E. and Björklund, K. (2009) Transport of Traffic-Related Microplastic Particles in Receiving Water. In: Mannina, G., Ed., New Trends in Urban Drainage Modelling, Springer International Publishing, Cham, 317-321. https://doi.org/10.1007/978-3-319-99867-1 53

[34] Kapp, K.J. and Miller, R.Z. (2020) Electric Clothes Dryers: An Underestimated Source of Microfiber Pollution. PLOS ONE, 15, e0239165.

https://doi.org/10.1371/journal.pone.0239165

[35] O’Brine, T., Thompson, R.O. and Brine, T. (2010) Degradation of Plastic Carrier Bags in the Marine Environment. Marine Pollution Bulletin, 60, 2279-2283. https://doi.org/10.1016/j.marpolbul.2010.08.005

[36] Sobhani, Z., Lei, Y., Tang, Y.H., Wu, L.W., Zhang, X., Naidu, R. and Mgharaj, M. (2020) Microplastics Generated When Opening Plastic Packaging. Scientific Reports, 10, Article No. 4841. https://doi.org/10.1038/s41598-020-61146-4

[37] Hidalgo-Ruz, V., Gutow, L., Thompson, R.C. and Thiel, M. (2012) Microplastics in the Marine Environment: A Review of the Methods Used for Identification and Quantification. Environmental Science \& Technology, 46, 3060-3075. https://doi.org/10.1021/es2031505

[38] Kubowicz, S. and Booth, A.M. (2017) Biodegradability of Plastics: Challenges and Misconceptions. Environmental Science \& Technology, 51, 12058-12060. https://doi.org/10.1021/acs.est.7b04051

[39] Sun, Q., Ren, S.Y. and Ni, H.G. (2020) Incidence of Microplastics in Personal Care Products: An Appreciable Part of Plastic Pollution. Science of the Total Environment, 742, Article ID: 140218. https://doi.org/10.1016/j.scitotenv.2020.140218

[40] Ustabasi, G.S. and Baysal, A. (2009) Occurrence and Risk Assessment of Microplastics from Various Toothpastes. Environmental Monitoring and Assessment, 191, Article No. 438. https://doi.org/10.1007/s10661-019-7574-1

[41] Cole, P., Lindeque, P., Halsband, C. and Galloway, T.S. (2011) Microplastics as Contaminants in the Marine Environment: A Review. Marine Pollution Bulletin, 62 , 
2588-2597. https://doi.org/10.1016/j.marpolbul.2011.09.025

[42] Sharma, S. and Chatterjee, S. (2017) Microplastic Pollution, a Threat to Marine Ecosystem and Human Health: A Short Review. Environmental Science and Pollution Research, 24, 21530-21547. https://doi.org/10.1007/s11356-017-9910-8

[43] Scudo, A., Liebermann, B., Corden, C., Tyrer, D., Kreissig, J. and Warwick, O. (2017) Intentionally Added Microplastics in Products-Final Report. Amec Foster Wheeler Environment \& Infrastructure UK Limited.

https://edi3-fs1/shared/data/projects/39168ppchemmicroplasticsrestriction/c000clie nt/reports/finalreport/39168 intentionallyaddedmicroplastics-finalreport 20171020 clean.docx

[44] Sundt, P., Schulze, P.-E. and Syversen, F. (2014/2015) Sources of Microplastic Pollution to the Marine Environment. Report No. M-321/2015, Mepex for the Norwegian Environment Agency, Miljødirektoratet, 86.

[45] Duis, F. and Coors, A. (2016) Microplastics in the Aquatic and Terrestrial Environment: Sources (with a Specific Focus on Personal Care Products), Fate and Effects. Environmental Sciences Europe, 28, 2.

[46] Magnusson, K. Eliasson, K., Fråne, A., Haikonen, K., Hultén, J., Olshammar, M., Stadmark, J. and Voisin, A. (2016) Swedish Sources and Pathways for Microplastics to the Marine Environment. Report C183, Swedish Environmental Research Institute, Stockholm (revised 2017).

[47] Lassen, C., Hansen, S.F., Magnusson, K., Norén, F., Hartmann, N.I.B., Jensen, P.R., Nielsen, T.G. and Brinch, A. (2015) Microplastics-Occurrence, Effects and Sources of Releases to the Environment in Denmark, Environmental Project No. 1973. Danish Ministry of the Environment, Environmental Protection Agency, Denmark, 204.

[48] Essel, R., Engel, L., Carus, M. and Ahrens, R.H. (2015) Sources of Microplastics Relevant to Marine Protection in Germany. Texte 64/2015 Project No. 31969 Report No. (UBA-FB) 002146/E, Federal Environment Agency, Germany.

[49] European Commission (DG Environment) (2017) Intentionally Added Microplastics in Products: Final Report (European Commission, Brussels) Doc Ref. $39168 \mathrm{Fi}$ nal Report 17271i3.

[50] Hernandez, L.M., Xu, E.G., Larsson, H.C.E., Tahara, R., Maisuria, V.B. and Tufenkji, N. (2019) Plastic Teabags Release Billions of Microparticles and Nanoparticles into Tea. Environmental Science \& Technology, 53, 12300-12310. https://doi.org/10.1021/acs.est.9b02540

[51] Zhang, Y., Kang, S., Allen, S., Aleen, D., Gao, T. and Sillanpää, M. (2020) Atmospheric Microplastics: A Review on Current Status and Perspectives. Earth-Science Reviews, 203, Article ID: 103118. https://doi.org/10.1016/j.earscirev.2020.103118

[52] Allen, S., Allen, D., Phoenix, V.R., Le Roux, G., Durańtez Giminéz, P., Simmoneau, A., Binet, S. and Galop, D. (2019) Atmospheric Transport and Deposition of Microplastics in a Remote Mountain Catchment. Nature Geoscience, 12, 339-344. https://doi.org/10.1038/s41561-019-0335-5

[53] Evangeliou, N., Grythe, H., Klimont, Z., Heyes, C., Eckhardt, S., Lopez-Aparicio, S. and Stohl, A. (2020) Atmospheric Transport Is a Major Pathway of Microplastics to Remote Regions. Nature Communications, 11, Article No. 3381. https://doi.org/10.1038/s41467-020-17201-9

[54] Hung, C., Klasios, N., Zhu, X., Sedlak, M., Sutton, R. and Rochman, C.M. (2020) Methods Matter: Methods for Sampling Microplastic and Other Anthropogenic Particles and Their Implications for Monitoring and Ecological Risk Assessment. 
Integrated Environmental Assessment Management, 17, 282-291. https://doi.org/10.1002/ieam.4325

[55] Kang, P.Y., Ji, B., Zhao, Y.G. and Wei, T. (2020) How Can We Trace Microplastics in Wastewater Treatment Plants: A Review of the Current Knowledge on Their Analysis Approaches. Science of the Total Environment, 745, Article ID: 140943. https://doi.org/10.1016/j.scitotenv.2020.140943

[56] Wang, Z., Lin, T. and Chen, W. (2020) Occurrence and Removal of Microplastics in an Advanced Drinking Water Treatment Plant (ADWTP). Science of the Total Environment, 700, Article ID: 134520. https://doi.org/10.1016/j.scitotenv.2019.134520

[57] Eriksen, M., Lebreton, L.C.M., Carson, H.S., Thiel, M., Moore, C.J., Borerro, J.C. Galgani, F., Ryan, P.G. and Reisser, J. (2014) Plastic Pollution in the World's Oceans: More than 5 Trillion Plastic Pieces Weighing over 250, 000 Tons Afloat at Sea. PLoS ONE, 9, e111913. https://doi.org/10.1371/journal.pone.0111913

[58] Michels, J., Stippkugel, A., Lenz, M., Wirtz, K. and Engel, A. (2018) Rapid Aggregation of Biofilm-Covered Microplastics with Marine Biogenic Particles. Proceedings of the Royal Society B, 285, Article ID: 20181203.

https://doi.org/10.1098/rspb.2018.1203

[59] Porter, A., Lyons, B.P., Galloway, T.S. and Lewis, C. (2018) Role of Marine Snows in Microplastic Fate and Bioavailability. Environmental Science and Technology, 52, 7111-7119. https://doi.org/10.1021/acs.est.8b01000

[60] van Sebille, E., Aliani, S., Lavender Law, K., Maximenko, N., Alsina, J.M., Bagaev, A., Bergmann, M., Chapron, B., Chubarenko, I., Cózar, A., Delandmeter, P., Egger, M., Fox-Kemper, B., Garaba, S.P., Goddijn-Murphy, L., Hardesty, B.D., Hoffman, M., Isobe, A., Jongedijk, C.E., Kaandorp, M.L.A., Khatmullina, L., Koelmans, A.A., Kukulka, T., Laufkötter, C., Lebreton, L., Lobelle, D., Maes, C., Martinez-Vicente, V., Maqueda, M.A.M., Poulain-Zarcos, M., Rodríguez, E., Ryan, P.G., Shanks, A.L., Shim, W.J., Suaria, G., Thiel, M., van den Bremer, T.S. and Wichmann, D. (2020) The Physical Oceanography of the Transport of Floating Marine Debris. Environmental Research Letters, 15, Article ID: 023003.

https://doi.org/10.1088/1748-9326/ab6d7d

[61] Corcoran, P.I. (2015) Benthic Plastic Debris in Marine and Fresh Water Environments. Environmental Science: Processes and Impacts, 17, 1363-1369. https://doi.org/10.1039/C5EM00188A

[62] Van Cauwenberghe, L., Vanreusel, A., Mees, J. and Janssen, C.R. (2013) Microplastic Pollution in Deep-Sea Sediments. Environmental Pollution, 182, 495-499.

https://doi.org/10.1016/j.envpol.2013.08.013

[63] Barrett, J., Chase, Z., Zhang, J., Banaszak Holl, M.M., Willis, K., Williams, A., Hardesty, B.D. and Wilcox, C. (2020) Microplastic Pollution in Deep-Sea Sediments from the Great Australian Bight. Frontiers in Marine Science, 7, Article ID: 576170. https://doi.org/10.3389/fmars.2020.576170

[64] Lebreton, L.C.M., van der Zwet, J., Damsteeq, J.-W., Slat, B., Andrady, A. and Reisser, J. (2017) River Plastic Emissions to the World's Oceans. Nature Communications, 8, Article No. 15611. https://doi.org/10.1038/ncomms15611

[65] Jambeck, J.R., Geyer, R., Wilcox, C., Siegler, T.R., Perryman, M., Narayan, R. and Law, K.L. (2015) Plastic Waste Inputs from Land into the Ocean. Science, 347, 768-771. https://doi.org/10.1126/science.1260352

[66] Webb, H.K., Arnott, J., Crawford, R.J. and Ivanova, E.P. (2013) Plastic Degradation and Its Environmental Implications with Special Reference to Poly(Ethylene Terephthalate). Polymers, 5, 1-18. https://doi.org/10.3390/polym5010001 
[67] Lucas, N., Bienaime, C., Belloy, C., Queneudec, M., Silvestre, F. and Nava-Saucedo, J.-E. (2008) Polymer Biodegradation: Mechanisms and Estimation Techniques: A Review. Chemosphere, 73, 429-442. https://doi.org/10.1016/j.chemosphere.2008.06.064

[68] Shah, A.A., Hasan, F., Hameed, A. and Ahmed, S. (2008) Biological Degradation of Plastics: A Comprehensive Review. Biotechnology Advances, 26, 246-265. https://doi.org/10.1016/j.biotechadv.2007.12.005

[69] Paço, A., Duarte, K., da Costa, J.P., Santos, P.S.M., Pereira, R., Pereira, M.E., Freitas, A.C., Duarte, A.C. and Rocha-Santos, T.A. (2017) Biodegradation of Polyethylene Microplastics by the Marine Fungus Zalerion maritimum. Science of the Total Environment, 586, 10-15. https://doi.org/10.1016/j.scitotenv.2017.02.017

[70] Auta, H.S., Emenike, C.U. and Fauziah, S.H. (2017) Screening of Bacillus Strains Isolated from Mangrove Ecosystems in Peninsular Malaysia for Microplastic Degradation. Environmental Pollution, 231, 1552-1559. https://doi.org/10.1016/j.envpol.2017.09.043

[71] Kelly, J.J., London, M.G., McCormick, A., Rojas, M., Scott, J.W. and Hoellein, T.J. (2021) Wastewater Treatment Alters Microbial Colonization of Microplastics. PLoS ONE, 16, e0244443. https://doi.org/10.1371/journal.pone.0244443

[72] Browne, M.A., Crump, P., Niven, S.J., Teuten, E., Tonkin, A., Galloway, T. and Thompson, R. (2011) Accumulation of Microplastic on Shorelines Worldwide: Sources and Sinks. Environmental Science \& Technology, 45, 9175-9179. https://doi.org/10.1021/es201811s

[73] Nizzetto, L., Futter, M. and Langaas, S. (2016) Are Agricultural Soils Dumps for Microplastics of Urban Origin? Environmental Science \& Technology, 50, 10777-10779. https://doi.org/10.1021/acs.est.6b04140

[74] Piehl, S., Leibner, A., Löder, M.G.J., Dris, R., Bogner, C. and Laforsch, C. (2018) Identification and Quantification of Macro- and Microplastics on an Agricultural Farmland. Scientific Reports, 8, Article No. 17950. https://doi.org/10.1038/s41598-018-36172-y

[75] Habib, D., Locke, D.C. and Cannone, L.J. (1998) Synthetic Fibers as Indicators of Municipal Sewage Sludge, Sludge Products and Sewage Treatment Plant Effluents. Water, Air, and Soil Pollution, 103, 1-8. https://doi.org/10.1023/A:1004908110793

[76] Napper, L.E., Bakir, A., Rowland, S.J. and Thompson, R.C. (2015) Characterization, Quantity and Sorptive Properties of Microplastics Extracted from Cosmetic. Marine Pollution Bulletin, 99, 178-185. https://doi.org/10.1016/j.marpolbul.2015.07.029

[77] Cesa, F.S., Turra, A. and Baruque-Ramos, J. (2017) Synthetic Fibers as Microplastics in the Marine Environment: A Review from Textile Perspective with a Focus on Domestic Washings. Science of the Total Environment, 598, 1116-1129. https://doi.org/10.1016/j.scitotenv.2017.04.172

[78] Guerranti, C., Martellini, T., Perra, G., Scopetani, C. and Cincinelli, A. (2019) Microplastics in Cosmetics: Environmental Issues and Needs for Global Bans. Environmental Toxicolcology and Pharmacology, 68, 75-79. https://doi.org/10.1016/j.etap.2019.03.007

[79] Anagnostia, L., Varvaresou, A., Pavlou, P., Protopapa, E. and Carayanni, V. (2021) Worldwide Actions against Plastic Pollution from Microbeads and Microplastics in Cosmetics Focusing on European Policies. Has the Issue Been Handled Effectively? Marine Pollution Bulletin, 162, Article ID: 111883. https://doi.org/10.1016/j.marpolbul.2020.111883

[80] Jonsson, C., Arturin, O.I., Hanning, A.-C., Landin, R., Holmstrom, E. and Roos, S. 
(2018) Microplastics Shedding from Textiles-Developing Analytical Method for Measurement of Shed Material Representing Release during Domestic Washing. Sustainability, 10, 2457. https://doi.org/10.3390/su10072457

[81] de Falco, F., Gullo, M.P., Gentile, G., Di Pace, E., Cocca, M., Gelabert, L., Brouta-Agnesa, M., Rovira, A., Escudero, R., Villalba, R., Mossotti, R., Montarsolo, A., Gavignano, S., Tonin, C. and Avella, M. (2018) Evaluation of Microplastic Release Caused by Textile Washing Processes of Synthetic Fabrics. Environmental Pollution, 236, 916-925. https://doi.org/10.1016/j.envpol.2017.10.057

[82] Thiemann, T. (2021) Microplastics in the United Arab Emirates: Tires, Cosmetics and Cutting Boards. Regional E-gathering in Chemistry, 9-10 March 2021. https://wp.nyu.edu/abudhabi-chemistry regional egathering/program/

[83] Talvitie, J., Mikola, A., Setälä, O., Heinonen, M. and Koistinen, A. (2017) How Well Is Microlitter Purified from Wastewater?-A Detailed Study on the Stepwise Removal of Microlitter in a Tertiary Level Wastewater Treatment Plant. Water Research, 109, 164-172. https://doi.org/10.1016/j.watres.2016.11.046

[84] Unice, K.M., Weeber, M.P., Abramson, M.M., Reid, R.C.D., van Gils, J.A.G., Markus, A.A., Vethaak, A.D. and Panko, J.M. (2019) Characterizing Export of Land-Based Microplastics to the Estuary-Part 1: Application of Integrated Geospatial Microplastic Transport Models to Assess Tire and Road Wear Particles in the Seine Watershed. Science of the Total Environment, 646, 1639-1649.

https://doi.org/10.1016/j.scitotenv.2018.07.368

[85] Unice, K.M., Weeber, M.P., Abramson, M.M., Reid, R.C.D., van Gils, J.A.G., Markus, A.A., Vethaak, A.D. and Panko, J.M. (2019) Characterizing Export of Land-Based Microplastics to the Estuary-Part II: Sensitivity Analysis of an Integrated Geospatial Microplastic Transport Modeling Assessment of Tire and Road Wear Particles. Science of the Total Environment, 646, 1650-1659. https://doi.org/10.1016/j.scitotenv.2018.08.301

[86] Baensch-Baltruschat, B., Kocher, B., Kochleus, C., Stock, F. and Reifferscheid, F.G. (2021) Tyre and Road Wear Particles-A Calculation of Generation, Transport and Release to Water and Soil with Special Regard to German Roads. Science of the Total Environment, 752, Article ID: 141939. https://doi.org/10.1016/j.scitotenv.2020.141939

[87] Thiemann, T. (2021) Isolation of Phthalates and Terephthalates from Plant Material-Natural Products or Contaminants? Open Journal of Chemistry (Bentham), 8 , $1-36$.

[88] Tian, Z., Zhao, H., Peter, K.T., Gonzalez, M., Wetzel, J., Wu, C., Hu, X., Prat, J., Mudrock, E., Hettinger, R., Cortina, A.E., Biswas, R.G., Kock, F.V.C., Soong, R., Jenne, A., Du, B., Hou, F., He, H., Lundeen, R., Gilbreath, A., Sutton, R., Scholz, N.L., Davis, J.W., Dodd, M.C., Simpson, A., McIntyre, J.K. and Kolodziej, E.P. (2021) A Ubiquitous Tire Rubber-Derived Chemical Induces Acute Mortality in Coho Salmon. Science, 371, 185-189.

[89] Liu, Y.D., Li, Z.Z., Jalon-Rojas, I., Wang, X.H., Fredj, E., Zhang, D.H., Feng, L.J. and Li, X.G. (2020) Assessing the Potential Risk and Relationship between Microplastics and Phthalates in Surface Seawater of a Heavily Human-Impacted Metropolitan Bay in Northern China. Ecotoxicology and Environmental Safety, 204, Article ID: 111067. https://doi.org/10.1016/j.ecoenv.2020.111067

[90] Murphy, F., Ewins, C., Carbonnier, F. and Quinn, B. (2016) Wastewater Treatment Works (WwTW) as a Source of Microplastics in the Aquatic Environment. Environmental Science \& Technology, 50, 5800-5808. 
https://doi.org/10.1021/acs.est.5b05416

[91] Dris, R., Gasperi, J., Rocher, V., Saad, M., Renault, N. and Tassin, B. (2015) Microplastic Contamination in an Urban Area: A Case Study in Greater Paris. Environmental Chemistry, 12, 592-599. https://doi.org/10.1071/EN14167

[92] Sutton, R., Mason, S.A., Stanek, S.K., Willis-Norton, E., Wren, I.F. and Box, C. (2016) Microplastic Contamination in the San Francisco bay, California, USA. Marine Pollution Bulletin, 109, 230-235.

https://doi.org/10.1016/j.marpolbul.2016.05.077

[93] Ziajahromi, S., Neale, P.A., Rintoul, L. and Leusch, F.D.L. (2017) Wastewater Treatment Plants as a Pathway for Microplastics: Development of a New Approach to Sample Wastewater-Based Microplastics. Water Research, 112, 93-99. https://doi.org/10.1016/j.watres.2017.01.042

[94] Mintenig, S.M., Int-Veen, I., Löder, M. and Gerdts. G. (2014) Mikroplastik in ausgewählten Kläranlagen des Oldenburgisch-Ostfriesischen Wasserverbandes (OOWV) in Niedersachsen. Probenanalyse mittels Mikro-FTIR Spektroskopie. [MikroPlastik in Selected Sewage Treatment Plants of the Oldenburgisch-Ostfriesischen Water Board in Niedersachsen. Sample Analysis Using Micro-FTIR Spectroscopy] Alfred-Wegener-Institut, Helmholtz-Zentrum für Polar- und Meeresforschung (AWI), Biologische Anstalt Helgoland. (In German)

[95] Lares, M., Ncibi, M.C., Sillanpää, M. and Sillanpää. M. (2018) Occurrence, Identification and Removal of Microplastic Particles and Fibers in Conventional Activated Sludge Process and Advanced MBR Technology. Water Research, 133, 236-246. https://doi.org/10.1016/j.watres.2018.01.049

[96] Magnusson, K. and Norén, F. (2014) Screening of Microplastic Particles in and Down-Stream a Wastewater Treatment Plant. Report C55, Swedish Environmental Research Institute, Stockholm.

[97] Dyachenko, A., Mitchell, J. and Arsem, N. (2017) Extraction and Identification of Microplastic Particles from Secondary Wastewater Treatment Plant (WWTP) Effluent. Analytical Methods, 9, 1412-1418. https://doi.org/10.1039/C6AY02397E

[98] Mason, S.A., Garneau, D., Sutton, R., Chu, Y., Ehmann, K., Barnes, J., Fink, P. Papazissimos, D. and Rogers, D. L. (2016) Microplastic Pollution Is Widely Detected in US Municipal Wastewater Treatment Plants Effluent. Environmental Pollution, 218, 1045-1054. https://doi.org/10.1016/j.envpol.2016.08.056

[99] Carr, S.A., Liu, J. and Tesoro, A.G. (2016) Transport and Fate of Microplastic Particles in Wastewater Treatment Plants. Water Research, 91, 174-182.

https://doi.org/10.1016/j.watres.2016.01.002

[100] Michielssen, M.R., Michielssen, E.R., Ni, J. and Duhaime, M.B. (2016) Fate of Microplastics and Other Anthropogenic Litter (SAL) in Wastewater Treatment Plants Depends on the Unit Processes Involved. Environmental Science. Water Research \& Technology, 2, 1064-1073. https://doi.org/10.1039/C6EW00207B

[101] Mintenig, S.M., Int-Veen, I., Löder, M.G.J., Primpke, S. and Gerdts, G. (2017) Identification of Microplastic in Effluents of Waste Water Treatment Plants Using Focal Plane Array-Based Micro-Fourier-Transform Infrared Imaging. Water Research, 108, 365-372. https://doi.org/10.1016/j.watres.2016.11.015

[102] Talvitie, J., Heinonen, M., Paakkonen, J.-P., Vahtera, E., Mikola, A., Setala, O. and Vahala, R. (2015) Do Wastewater Treatment Plants Act as a Potential Point Source of Microplastics? Preliminary Study in Coastal Gulf of Finland, Baltic Sea. Water Science \& Technology, 72, 1495-1504. https://doi.org/10.2166/wst.2015.360

[103] Talvitie, J. (2018) Wastewater Treatment Plants as Pathways of Microliter to the 
Aquatic Environment. Doctoral Thesis, Aalto University, Helsinki, 106.

[104] Leslie, H.A., Brandsma, S.H., van Velzen, M.J.M. and Vethaak, A.D. (2017) Microplastics en Route: Field Measurements in the Dutch River Delta and Amsterdam Canals, Wastewater Treatment Plants, North Sea Sediments and Biota. Environment International, 101, 133-142. https://doi.org/10.1016/j.envint.2017.01.018

[105] Talvitie, J. and Heinonen, M. (2014) Preliminary Study on Synthetic Microfibers and Particles at a Municipal Waste Water Treatment Plant. HELCOM BASE Project-Implementation of the Baltic Sea Action Plan in Russia.

[106] Gündoğdu, S., Çevik, C., Güzel, E. and Kilercioğlu, S. (2018) Microplastics in Municipal Wastewater Treatment Plants in Turkey: A Comparison of the Influent and Secondary Effluent Concentrations. Environmental Monitoring and Assessment, 190, 626-632. https://doi.org/10.1007/s10661-018-7010-y

[107] Kalčíková, G., Alič, B., Skalar, T., Bundschuh, M. and Žgajnar Gotvajn, A. (2017) Wastewater Treatment Plant Effluents as Source of Cosmetic Microbeads to Freshwater. Chemosphere, 188, 25-31.

https://doi.org/10.1016/j.chemosphere.2017.08.131

[108] Ren, P.J., Dou, M., Wang, C., Li, G.Q. and Jia, R.P. (2020) Abundance and Removal Characteristics of Microplastics at a Wastewater Treatment Plant in Zhengzhou. Environmental and Science Pollution Research, 27, 36295-36305. https://doi.org/10.1007/s11356-020-09611-5

[109] Edo, C., Gonzalez-Pleiter, M., Leganes, F., Fernandez-Pinas, F. and Rosal, R. (2020) Fate of Microplastics in Wastewater Treatment Plants and Their Environmental Dispersion with Effluent and Sludge. Environmental Pollution, 259, Article ID: 113837. https://doi.org/10.1016/j.envpol.2019.113837

[110] Bayo, J., López-Castellanos, J. and Olmos, S. (2020) Membrane Bioreactor and Rapid Sand Filtration for the Removal of Microplastics in an Urban Wastewater Treatment Plant. Marine Pollution Bulletin, 156, Article ID: 111211. https://doi.org/10.1016/j.marpolbul.2020.111211

[111] Blair, R.M., Waldron, S. and Gauchotte-Lindsay, C. (2019) Average Daily Flow of Microplastics through a Tertiary Wastewater Treatment Plant over a Ten-Month Period. Water Research, 163, Article ID: 114909.

https://doi.org/10.1016/j.watres.2019.114909

[112] Conley, K., Clum, A., Deepe, J., Lane, H. and Beckingham, B. (2019) Wastewater Treatment Plants as a Source of Microplastics to an Urban Estuary: Removal Efficiencies and Loading per Capita over One Year. Water Research X, 3, Article ID: 100030. https://doi.org/10.1016/j.wroa.2019.100030

[113] Simon, M., van Alst, N. and Vollertsen, J (2018) Quantification of Microplastic Mass and Removal Rates at Wastewater Treatment Plants Applying Focal Plane Array (FPA)-Based Fourier Transform Infrared (FT-IT) Imaging. Water Research, 142, 1-9. https://doi.org/10.1016/j.watres.2018.05.019

[114] Talvitie, J., Mikola, A., Koistinen, A. and Setälä, O. (2017) Solutions to Microplastic Pollution-Removal of Microplastics from Wastewater Effluents with Advanced Wastewater Treatment Technologies. Water Research, 123, 401-407. https://doi.org/10.1016/j.watres.2017.07.005

[115] Magni, S., Binelli, A., Pittura, L., Avio, C.G., della Torre, C., Parenti, C.C., Gorbi, S. and Regoli, F. (2019) The Fate of Microplastics in an Italian Wastewater Treatment Plant. Science of the Total Environment, 652, 602-610. https://doi.org/10.1016/j.scitotenv.2018.10.269

[116] Hidayaturrahman, H. and Lee, T.G. (2019) A Study on Characteristics of Micro- 
plastic in Wastewater in South Korea: Identification, Quantification, and Fate of Microplastics in Treatment Process. Marine Pollution Bulletin, 146, 696-702. https://doi.org/10.1016/j.marpolbul.2019.06.071

[117] Tagg, A.S., Sapp, M., Harrison, J.P., Sinclair, C.J., Bradley, E., Ju-Nam, Y. and Ojeda, J.J. (2020) Microplastic Monitoring at Different Stages in a Wastewater Treatment Plant Using Reflectance Micro-FTIR Imaging. Frontiers in Environmental Science, 8, 145. https://doi.org/10.3389/fenvs.2020.00145

[118] Estahbani, S. and Fahrenfeld, N.L. (2016) Influence of Wastewater Treatment Plant Discharges on Microplastic Concentrations in Surface Water. Chemosphere, 162, 277-284. https://doi.org/10.1016/j.chemosphere.2016.07.083

[119] Gies, E.A., LeNoble, J.L., Noël, M., Etemadifar, A., Bishay, F., Hall, E.R. and Ross, P.S. (2018) Retention of Microplastics in a Major Secondary Wastewater Treatment Plant in Vancouver, Canada. Marine Pollution Bulletin, 133, 553-561. https://doi.org/10.1016/j.marpolbul.2018.06.006

[120] Wisniowska, E., Moraczewska-Majkut, K. and Nocon, W. (2018) Efficiency of Microplastics Removal in Selected Wastewater Treatment Plants-Preliminary Studies. Desalination and Water Treatment, 134, 316-323. https://doi.org/10.5004/dwt.2018.23418

[121] Yang, L., Li, K., Cui, S., Kang, Y., An, L. and Lei, K. (2019) Removal of Microplastics in Municipal Sewage from China's Largest Water Reclamation Plant. Water Research, 155, 175-181. https://doi.org/10.1016/j.watres.2019.02.046

[122] Bayo, J., Olmos, S. and López-Castellanos, J. (2019) Microplastics in an Urban Wastewater Treatment Plant: The Influence of Physicochemical Parameters and Environmental Factors. Chemosphere, 238, Article ID: 124593.

https://doi.org/10.1016/j.chemosphere.2019.124593

[123] Long, Z., Pan, Z., Wang, W., Ren, J., Yu, X., Lin, L., Lin, H. Chen, H. and Jin, X. (2019) Microplastic Abundance, Characteristics, and Removal in Wastewater Treatment Plants in a Coastal City of China. Water Research, 155, 255-265. https://doi.org/10.1016/j.watres.2019.02.028

[124] Xu, X., Jian, Y., Xue, Y., Hou, Q. and Wang, L. (2019) Microplastics in the Wastewater Treatment plants (WWTPs): Occurrence and Removal. Chemosphere, 235, 1089-1096. https://doi.org/10.1016/j.chemosphere.2019.06.197

[125] Lv, X., Dong, Q., Zuo, Z., Liu, Y., Huang, X. and Wu, W.M. (2019) Microplastics in a Municipal Wastewater Treatment Plant: Fate, Dynamic Distribution, Removal Efficiencies, and Control Strategies. Journal of Cleaner Production, 225, 579-586. https://doi.org/10.1016/j.jclepro.2019.03.321

[126] Liu, X., Yuan, W., Di, M., Li, Z. and Wang, J. (2019) Transfer and Fate of Microplastics during the Conventional Activated Sludge Process in One Wastewater Treatment Plant of China. Chemical Engineering Journal, 362, 176-182. https://doi.org/10.1016/j.cej.2019.01.033

[127] Wolff, S., Kerpen, J., Prediger, J., Barkmann, L. and Müller, L. (2019) Determination of the Microplastics Emission in the Effluent of A Municipal Wastewater Treatment Plant Using Raman Microspectroscopy. Water Research X, 2, Article ID: 100014. https://doi.org/10.1016/j.wroa.2018.100014

[128] Ziajahromi, S., Neale, P.A., Silveira, I.T., Chua, A. and Leusch, F.D.L. (2021) An Audit of Microplastic Abundance Throughout Three Australian Wastewater Treatment Plants. Chemosphere, 263, Article ID: 128294.

https://doi.org/10.1016/j.chemosphere.2020.128294

[129] Wei, S., Luo, H., Zou, J., Chen, J., Pan, X., Rousseau, D.P.L. and Li., J. (2020) Cha- 
racteristics and Removal of Microplastics in Rural Domestic Wastewater Treatment Facilities of China. Science of the Total Environment, 739, Article ID: 139935. https://doi.org/10.1016/j.scitotenv.2020.139935

[130] Petroody, S.S.A., Hashemi, H. and van Gestel. C.A.M. (2020) Factors Affecting Microplastic Retention and Emission by a Wastewater Treatment Plant on the Southern Coast of Caspian Sea. Chemosphere, 261, Article ID: 128179. https://doi.org/10.1016/j.chemosphere.2020.128179

[131] Ben-David, E., Habibi, M., Haddad, E., Angel, D.L., Booth, A.M. and Sabbah, I. (2021) Microplastic Distributions in a Domestic Wastewater Treatment Plant: Removal Efficiency, Seasonal Variation and Influence of Sampling Technique. Science of the Total Environment, 752, Article ID: 141880.

https://doi.org/10.1016/j.scitotenv.2020.141880

[132] Akarsu, C., Kumbur, H., Gödağ, K., Kideys, A.E. and Sanchez-Vidal, A. (2020) Microplastics Composition and Load from Three Wastewater Treatment Plants Discharging into Mersin Bay, North Eastern Mediterranean Sea. Marine Pollution Bulletin, 150, Article ID: 110776. https://doi.org/10.1016/j.marpolbul.2019.110776

[133] Naji, A., Azadkhah, S., Farahani, H., Uddin, S. and Khan, F.R. (2021) Microplastics in Wastewater Outlets of Bandar Abbas City (Iran): A Potential Point Source of Microplastics into the Persian Gulf. Chemosphere, 262, Article ID: 128039. https://doi.org/10.1016/j.chemosphere.2020.128039

[134] Mak, C.W.D., Tsang, Y.Y., Leung, M.L.M., Fang, J.K.H. and Chan, K.M. (2020) Microplastics from Effluents of Sewage Treatment Works and Stormwater Discharging into the Victoria Harbor, Hong Kong. Marine Pollution Bulletin, 157, Article ID: 111181. https://doi.org/10.1016/j.marpolbul.2020.111181

[135] Zhou, H., Zhou, L. and Ma, K. (2020) Microfiber from Textile Dyeing and Printing Wastewater of a Typical Industrial Park in China: Occurrence, Removal and Release. Science of the Total Environment, 739, Article ID: 140329. https://doi.org/10.1016/j.scitotenv.2020.140329

[136] Tang, N., Liu, X. and Xing, W. (2020) Microplastics in Wastewater Treatment Plants of Wuhan, Central China: Abundance, Removal, and Potential Source in Household Wastewater. Science of the Total Environment, 745, Article ID: 141026. https://doi.org/10.1016/j.scitotenv.2020.141026

[137] Park, H.J., Oh, M.-J., Kim, P-G., Kim, G., Jeong, D.H., Ju, B.K., Lee, W-S., Chung, H.M., Kang, H.J. and Kwon, J.H. (2020) National Reconnaissance Survey of Microplastics in Municipal Wastewater Treatment Plants in Korea. Environmental Science \& Technology, 54, 1503-1512. https://doi.org/10.1021/acs.est.9b04929

[138] Rajala, K., Grönfors, O., Hesampour, M. and Mikola, A. (2020) Removal of Microplastics from Secondary Wastewater Treatment Plant Effluent by Coagulation/Flocculation with Iron, Aluminium and Polyamine-Based Chemicals. Water Research, 183, Article ID: 116045. https://doi.org/10.1016/j.watres.2020.116045

[139] Nguyen, N.B., Kim, M.-K., Le, Q.T., Ngo, D.N., Zoh, K.-D. and Joo, S.-W. (2021) Spectroscopic Analysis of Microplastic Contaminants in an Urban Wastewater Treatment Plant from Seoul, South Korea. Chemosphere, 263, Article ID: 127812. https://doi.org/10.1016/j.chemosphere.2020.127812

[140] Alvim, C.B., Bles-Piá, M.A. and Mendoza-Roca, J.A. (2020) Separation and Identification of Microplastics from Primary and Secondary Effluents and Activated Sludge from Wastewater Treatment Plants. Chemical Engineering Journal, 402, Article ID: 126293. https://doi.org/10.1016/j.cej.2020.126293

[141] Yuan, F., Zhao, H. Sun, H., Zhao, J. and Sun, Y. (2021) Abundance, Morphology, 
and Removal Efficiency of Microplastics in Two Wastewater Treatment Plants in Nanjing, China. Environmental Science and Pollution Research International, 28, 9327-9337. https://doi.org/10.1007/s11356-020-11411-w

[142] Pittura, L., Foglia, A., Akyol, C., Cipolletta, G., Benedetti, M., Regoli, F., Eusebi, A.L., Sabbatini, S., Tseng, L.Y., Katsou, E., Gorbi, S. and Fatone, F. (2021) Microplastics in Real Wastewater Treatment Schemes: Comparative Assessment and Relevant Inhibition Effects on Anaerobic Processes. Chemosphere, 262, Article ID: 128415. https://doi.org/10.1016/j.chemosphere.2020.128415

[143] Zou, Y., Ye, C. and Pan, Y. (2021) Abundance and Characteristics of Microplastics in Municipal Wastewater Treatment Plant Effluent: A Case Study of Guangzhou, China. Environmental Science and Pollution Research International, 28, 11572-11585. https://doi.org/10.1007/s11356-020-11431-6

[144] Raju, S., Carbery, M., Kuttykattil, A., Senthirajah, K., Lundmark, A., Rogers, Z., Suresh, S.C.B., Evans, G. and Palanisami, T. (2020) Improved Methodology to Determine the Fate and Transport of Microplastics in a Secondary Wastewater Treatment Plant. Water Research, 173, Article ID: 115549. https://doi.org/10.1016/j.watres.2020.115549

[145] Ferreira, M., Thompson, J., Paris, A., Rohindra, D. and Rico, C. (2020) Presence of Microplastics in Water, Sediments and Fish Species in an Urban Coastal Environment of Fiji, a Pacific Small Island Developing State. Marine Pollution Bulletin, 153, Article ID: 110991. https://doi.org/10.1016/j.marpolbul.2020.110991

[146] Schmidt, C., Kumar, R., Yang, S. and Büttner, O. (2020) Microplastic Particle Emission from Wastewater Treatment Plant Effluents into River Networks in Germany: Loads, Spatial Patterns of Concentrations and Potential Toxicity. Science of the Total Environment, 737, Article ID: 139544. https://doi.org/10.1016/j.scitotenv.2020.139544

[147] Frehland, S., Kaegi, R., Hufenus, R. and Mitrano, D.M. (2020) Long-Term Assessment of Nanoplastic Particles and Microplastic Fiber Flux through a Pilot Wastewater Treatment Plant Using Metal-Doped Plastics. Water Research, 182, Article ID: 115860. https://doi.org/10.1016/j.watres.2020.115860

[148] Elkhatib, D. and Oyanedel-Carver, V. (2020) A Critical Review of Extraction and Identification Methods of Microplastics in Wastewater and Drinking Water. Environmental Science \& Technology, 54, 7037-7049. https://doi.org/10.1021/acs.est.9b06672

[149] Löder, M.G.J., Kuczera, M., Mintenig, S., Lorenz, C. and Gerdts, G. (2015) Focal Plane Array Detector-Based Micro-Fourier-Transform Infrared Imaging for the Analysis of Microplastics in Environmental Samples. Environmental Chemistry, 12, 563-581. https://doi.org/10.1071/EN14205

[150] Fang, C., Sobhani, Z., Zhang, X., Gibson, C.T., Tang, Y. and Naidu, R. (2020) Identification and Visualisation of Microplastics/Nanoplastics by Raman Imaging (ii): Smaller than the Diffraction Limit of Laser? Water Research, 183, Article ID: 116048. https://doi.org/10.1016/j.watres.2020.116046

[151] Fortin, S., Song, B. and Burbage, C. (2019) Quantifying and Identifying Microplastics in the Effluent of Advanced Wastewater Treatment Systems Using Raman Microspectroscopy. Marine Pollution Bulletin, 149, Article ID: 110579. https://doi.org/10.1016/j.marpolbul.2019.110579

[152] Alimi, O., Budarz, J., Hernandez, L. and Tufenkji, N. (2018) Microplastics and Nanoplastics in Aquatic Environments: Aggregation, Deposition, and Enhanced Contaminant Transport. Environmental Science \& Technology, 52, 1704-1724. 
https://doi.org/10.1021/acs.est.7b05559

[153] McCormick, A., Hoellein, T.J., Mason, S.A., Schluep, J. and Kelly, J.J. (2016) Microplastic in Surface Waters of Urban Rivers: Concentration, Sources, and Associated Bacterial Assemblages. Ecosphere, 7, e01556. https://doi.org/10.1002/ecs2.1556

[154] Olds, H.T., Corsi, S.R., Dila, D.K., Halmo, K.M., Bootsma, M.J. and McLellan, S.L. (2018) High Levels of Sewage Contamination Released from Urban Areas after Storm Events: A Quantitative Survey with Sewage Specific Bacterial Indicators. PLoS Medicine, 15, e1002614. https://doi.org/10.1371/journal.pmed.1002614

[155] Tong, M., He, L., Rong, H., Li, M. and Kim, H. (2020) Transport Behaviors of Plastic Particles in Saturated Quartz Sand without and with Biochar/ $\mathrm{Fe}_{3} \mathrm{O}_{4}$-Biochar Amendment. Water Research, 169, Article ID: 115284. https://doi.org/10.1016/j.watres.2019.115284

[156] Poerio, T., Piacentini, E. and Mazzei, R. (2019) Membrane Processes for Microplastic Removal. Molecules, 24, 4148. https://doi.org/10.3390/molecules24224148

[157] Ma, B., Xue, W., Ding, Y., Hu, C., Liu, H. and Qu, J. (2019) Removal Characteristics of Microplastics by Fe-Based Coagulants during Drinking Water Treatment. Journal of Environmental Sciences, 78, 267-275.

https://doi.org/10.1016/j.jes.2018.10.006

[158] Ma, B., Xue, W., Hu, C., Liu, H., Qu, J. and Li, L. (2019) Characteristics of Microplastic Removal via Coagulation and Ultrafiltration during Drinking Water Treatment. Chemical Engineering Journal, 359, 159-167.

https://doi.org/10.1016/j.cej.2018.11.155

[159] Li, L., Liu, D., Song, K. and Zhou, Y. (2020) Performance Evaluation of MBR in Treating Microplastics Polyvinylchloride Contaminated Polluted Surface Water. Marine Pollution Bulletin, 150, Article ID: 110724. https://doi.org/10.1016/j.marpolbul.2019.110724

[160] Brandsma, S.H., Nijssen, P., van Velzen, M.J.M. and Leslie, H.A. (2013) Microplastics in River Suspended Particulate Matter and Sewage Treatment Plants. Report R14/02, Version 1, IVM Institute for Environmental Studies, Amsterdam.

[161] Mahon, A.M., O’Connell, B., Healy, M.G., O’Connor, I., Officer, R., Nash, R. and Morrison, L. (2017) Microplastics in Sewage Sludge: Effects of Treatment. Environmental Science \& Technology, 51, 810-818.

https://doi.org/10.1021/acs.est.6b04048

[162] Bayo, J., Olmos, S., Lopez-Castellanos, J. and Alcolea, A. (2016) Microplastics and Microfibers in the Sludge of a Municipal Wastewater Treatment Plant. International Journal of Sustainable Development and Planning, 11, 812-821. https://doi.org/10.2495/SDP-V11-N5-812-821

[163] Lusher, A., Hurley, R., Vogelsang, C., Nizzetto, L. and Olsen, M. (2018) Mapping Microplastics in Sludge. Technical Report L.NR. 7215-2017 (NIVA).

[164] Sujathan, S., Kniggendorf, A.-K., Kumar, A., Roth, B., Rosenwinkel, K.H. and Nogueira, R. (2017) Heat and Bleach: A Cost-Efficient Method for Extracting Microplastics from Return Activated Sludge. Archives of Environmental Contamination and Toxicology, 73, 641-648. https://doi.org/10.1007/s00244-017-0415-8

[165] Zubris, K.A.V. and Richards, B.K. (2005) Synthetic Fibers as an Indicator of Land Application of Sludge. Environmental Pollution, 138, 201-211. https://doi.org/10.1016/j.envpol.2005.04.013

[166] Li, X.W., Chen, L.B., Mei, Q.Q., Dong, B., Dai, X.H., Ding, G.J. and Zeng, E.Y. (2018) Microplastics in Sewage Sludge from the Wastewater Treatment Plants in 
China. Water Research, 142, 75-85. https://doi.org/10.1016/j.watres.2018.05.034

[167] Prata, J.C. (2018) Microplastics in Wastewater: State of Knowledge on Sources, Fate and Solution. Marine Pollution Bulletin, 129, 262-265.

https://doi.org/10.1016/j.marpolbul.2018.02.046

[168] Gao, D., Li, X.Y. and Liu, H.T. (2020) Source, Occurrence, Migration and Potential Environmental Risk of Microplastics in Sewage Sludge and during Sludge Amendment to Soil. Science of the Total Environment, 742, Article ID: 140335. https://doi.org/10.1016/j.scitotenv.2020.140355

[169] van den Berg, P., Huerta-Lwanga, E., Corradini, F. and Geissen, V. (2020) Sewage Sludge Application as a Vehicle for Microplastics in Eastern Spanish Agricultural Soils. Environmental Pollution, 261, Article ID: 114198. https://doi.org/10.1016/j.envpol.2020.114198

[170] Xu, Q.J., Gao, Y.Y., Xu, L., Shi, W.Z., Wang, F.F., LeBlanc, G.A., Cui, S., An, L.H. and Lei, K. (2020) Investigation of the Microplastics Profile in Sludge from China's largest Water Reclamation Plant Using a Feasible Isolation Device. Journal of Hazardous Materials, 388, Article ID: 122067. https://doi.org/10.1016/j.jhazmat.2020.122067

[171] Zhou, Q., Tian, C. and Luo, Y. (2017) Various Forms and Deposition Fluxes of Microplastics Identified in the Coastal Urban Atmosphere. Chinese Science Bulletin, 62, 3902-3909. https://doi.org/10.1360/N972017-00956

[172] He, D., Luo, Y., Lu, S., Liu, M. Song, Y. and Lei, L. (2018) Microplastics in Soils: Analytical Methods, Pollution Characteristics and Ecological Risks. Trends in Analytical Chemistry, 109, 163-172. https://doi.org/10.1016/j.trac.2018.10.006

[173] Chae, Y. and An, Y.-J. (2017) Effects of Micro- and Nanoplastics on Aquatic Ecosystems: Current Research Trends and Perspectives. Marine Pollution Bulletin, 124, 624-632. https://doi.org/10.1016/j.marpolbul.2017.01.070

[174] Hurley, R.R. and Nizzetto, L. (2018) Fate and Occurrence of Micro(Nano)Plastics in Soils: Knowledge Gaps and Possible Risks. Current Opinion Environmental Science \& Health, 1, 6-11. https://doi.org/10.1016/j.coesh.2017.10.006

[175] Bläsing, M. and Amelung, W. (2018) Plastics in Soil: Analytical Methods and Possible Sources. Science of the Total Environment, 612, 422-435.

https://doi.org/10.1016/j.scitotenv.2017.08.086

[176] de Souza Machado, A.A., Kloas, W., Zarfl, C., Hempel, S. and Rillig, M.C. (2018) Microplastics as an Emerging Threat to Terrestrial Ecosystems. Global Change Biology, 24, 1405-1416. https://doi.org/10.1111/gcb.14020

[177] Ali, M.I., Ahmed, S., Robson, G., Javed, I., Ali, N., Atiq, N. and Hameed, A. (2014) Isolation and Molecular Characterization of Polyvinyl Chloride (PVC) Plastic Degrading Fungal Isolates. Journal of Basic Microbiology, 54, 18-27. https://doi.org/10.1002/jobm.201200496

[178] Andrady, A.L. (2017) The Plastic in Microplastics: A Review. Marine Pollution Bulletin, 119, 12-22. https://doi.org/10.1016/j.marpolbul.2017.01.082

[179] Li, L., Geng, S., Li, Z. and Song, K. (2020) Effect of Microplastic on Anaerobic Digestion of Waste Activated Sludge. Chemosphere, 247, Article ID: 125874. https://doi.org/10.1016/j.chemosphere.2020.125874

[180] Wei, W., Huang, Q.S., Sun, J., Dai, X. and Ni, B.-J. (2019) Revealing the Mechanisms of Polyethylene Microplastics Affecting Anaerobic Digestion of Waste Activated Sludge. Environmental Science and Technology, 53, 9604-9613. https://doi.org/10.1021/acs.est.9b02971 
[181] Wei, W., Huang, Q.S., Sun, J., Wang, J.Y., Wu, S.L. and Ni, B.-J. (2019) Polyvinyl chloride Microplastics Affect Methane Production from the Anaerobic Digestion of Waste Activated Sludge through Leaching Toxic Bisphenol-A. Environmental Science and Technology, 53, 2509-2517. https://doi.org/10.1021/acs.est.8b07069

[182] Zhang, Y.T., Wei, W., Huang, Q.S., Wang, C., Wang, Y. and Ni, B. (2020) Insights into the Micropbial Response of Anaerobic Ranular Sludge during Long-Term Exposure to Polyethylene Terephthalate Microplastics. Water Research, 179, Article ID: 115898. https://doi.org/10.1016/j.watres.2020.115898

[183] Fu, S.F., Ding, J.N., Zhang, Y., Li, Y.F., Zhu, R. Yuan, X.Z. and Zou, H. (2018) Exposure to Polystyrene Nanoplastic Leads to Inhibition of Anaerobic Digestion System. Science of the Total Environment, 625, 64-70. https://doi.org/10.1016/j.scitotenv.2017.12.158

[184] Rom, M., Fabia, J., Grubel, K., Sarna, E., Graczyk, T. and Janicki, J. (2017) Study of the Biodegradability of Polylactide Fibers in Wastewater Treatment Processes. Polimery, 62, 834-840. https://doi.org/10.14314/polimery.2017.834

[185] Tiwari, E., Singh, N., Khandelwal, N., Monikh, F.A. and Darbha, G.K. (2020) Application of $\mathrm{Zn} / \mathrm{Al}$ Layered Double Hydroxides for the Removal of Nano-Scale Plastic Debris from Aqueous Systems. Journal of Hazardous Materials, 397, Article ID: 122769. https://doi.org/10.1016/j.jhazmat.2020.122769

[186] Sun, C., Wang, Z., Chen, L. and Li, F. (2020) Fabrication of Robust and Comprehensive Chitin and Graphene Oxide Sponges for Removal of Microplastics with Different Functional Groups. Chemical Engineering Journal, 393, Article ID: 124796. https://doi.org/10.1016/j.cej.2020.124796

[187] Wang, Z., Sedighi, M. and Lea-Langton, A. (2020) Filtration of Microplastic Spheres by Biochar: Removal Efficiency and Immobilisation Mechanism. Water Research, 184, Article ID: 116165. https://doi.org/10.1016/j.watres.2020.116165

[188] Akarsu, C. and Deniz, F. (2021) Electrocoagulation/Electroflotation Process for Removal of Organics and Microplastics in Laundry Wastewater. CLEAN: Soil, Air, Water, 49, Article ID: 2000146. https://doi.org/10.1002/clen.202000146

[189] Perren, W., Wojtasik, A. and Cai, Q. (2018) Removal of Microbeads from Wastewater Using Electrocoagulation. ACS Omega, 3, 3357-3364.

https://doi.org/10.1021/acsomega.7b02037

[190] Zhou, G., Wang, Q., Li, J., Li, Q., Xu, H., Ye, Q., Wang, Y., Shu, S. and Zhang, J. (2021) Removal of Polystyrene and Polyethylene Microplastics Using PAC and $\mathrm{FeCl}_{3}$ Coagulation: Performance and Mechanism. Science of the Total Environment, 752, Article ID: 141837. https://doi.org/10.1016/j.scitotenv.2020.141837

[191] Skaf, D.W., Punzi, V.L., Rolle, J.T. and Kleinberg, K.A. (2020) Removal of Micron-Sized Microplastic Particles from Simulated Drinking Water via Alum Coagulation. Chemical Engineering Journal, 386, Article ID: 123807. https://doi.org/10.1016/j.cej.2019.123807

[192] Shahi, N.K., Maeng, M., Kim, D. and Doccko, S. (2020) Removal Behaviour of Microplastics Using Alum Coagulant and Its Enhancement Using Polyamine-Coated Sand. Process Safety and Environmental Protection, 141, 9-17. https://doi.org/10.1016/j.psep.2020.05.020

[193] Larue, O., Vorobiev, E., Vu, C. and Durand, B. (2003) Electrocoagulation and Coagulation by Iron of Latex Particles in Aqueous Suspensions. Separation and Purification Technology, 31, 177-192. https://doi.org/10.1016/S1383-5866(02)00182-X

[194] Lapointe, M., Farner, J.M., Hernandez, L.M. and Tufenkji, N. (2020) Understanding 
and Improving Microplastic Removal during Water Treatment Impact of Coagulation and Flocculation. Environmental Science \& Technology, 54, 8719-8727. https://doi.org/10.1021/acs.est.0c00712

[195] Mintenig, S.M., Löder, M.G.J., Primpke, A. and Gerdts, G. (2019) Low Number of Microplastics Detected in Drinking Water from Ground Water Sources. Science of the Total Environment, 648, 631-635.

https://doi.org/10.1016/j.scitotenv.2018.08.178

[196] Pivokonsky, M., Cermakova, L., Novotna, K., Peer, P., Caithaml, T. and Janda, V. (2018) Occurrence of Microplastics in Raw and Treated Drinking Water. Science of the Total Environment, 643, 1644-1651. https://doi.org/10.1016/j.scitotenv.2018.08.102

[197] Novotna, K., Cermakova, L., Pivokonska, L., Cajthaml, T. and Pivokonsky, M. (2019) Microplastics in Drinking Water Treatment-Current Knowledge and Research Needs. Science of the Total Environment, 667, 730-740.

https://doi.org/10.1016/j.scitotenv.2019.02.431

[198] Shen, M., Song, B., Zhu, Y., Zheng, G., Zhang, Y., Yang, Y., Wen, X., Chen, M. and Yi, H. (2020) Removal of Microplastics via Drinking Water Treatment: Current Knowledge and Future Directions. Chemosphere, 251, Article ID: 126612. https://doi.org/10.1016/j.chemosphere.2020.126612

[199] Eerkes-Medrano, D., Leslie, H.A. and Quinn, B. (2018) Microplastics in Drinking Water: A Review and Assessment of Emerging Concern. Current Opinion in Environmental Science \& Health, 7, 69-75. https://doi.org/10.1016/j.coesh.2018.12.001

[200] Oßmann, B.E., Sarau, G., Holtmannspötter, H., Pischetsrieder, M., Christiansen, S.H. and Dicke, W. (2018) Small-Sized Microplastics and Pigmented Particles in Bottled Mineral Water. Water Research, 141, 307-316.

https://doi.org/10.1016/j.watres.2018.05.027

[201] Schymanski, D., Goldbeck, C., Humpf, H.U. and Furst, P. (2018) Analysis of Microplastics in Water by micro-Raman Spectroscopy: Release of Plastic Particles from Different Packaging into Mineral Water. Water Research, 129, 154-162. https://doi.org/10.1016/j.watres.2017.11.011

[202] Zuccarello, P., Ferrante, M., Cristaldi, A., Copat, C., Grasso, A., Sangegorio, D., Fiore, M. and Oliveri Conti, G. (2019) Exposure to Microplastics $(<10 \mu \mathrm{m})$ Associated to Plastic Bottles Mineral Water Consumption: The First Quantitative Study. Water Research, 157, 365-371. https://doi.org/10.1016/j.watres.2019.03.091

[203] Kosuth, M., Mason, S.A. and Wattenberg, E.V. (2018) Anthropogenic Contamination of Tap Water, Beer, and Sea Salt. PLOS ONE, 13, e0194970. https://doi.org/10.1371/journal.pone.0194970

[204] Chen, Z., Liu, J., Chen, C. and Huang, Z. (2020) Sedimentation of Nanoplastics from Water with $\mathrm{Ca} / \mathrm{Al}$ Dual Flocculants: Characterization, Interface Reaction, Effects of $\mathrm{pH}$ and Ion Ratios. Chemosphere, 252, Article ID: 126450. https://doi.org/10.1016/j.chemosphere.2020.126450

[205] Wahlström, R., Kalliola, A., Heikkinen, J., Kyllönen, H. and Tamminen, T. (2017) Lignin Cationization with Glycidyltrimethylammonium Chloride Aiming at Water Purification Applications. Industrial Crops and Products, 104, 188-194. https://doi.org/10.1016/j.indcrop.2017.04.026

[206] Magalhães, S., Alves, L., Medronho, B., Romano, A. and Rasteiro, M.G. (2020) Microplastics in Ecosystems: From Current Trends to Bio-Based Removal Strategies. Molecules, 25, 3954. https://doi.org/10.3390/molecules25173954

[207] Laszlo, J.A. (1999) Solubility and Dye-Binding Properties of Quaternized and Pe- 
roxidase-Polymerized Kraft Lignin. Environmental Technology, 20, 607-615. https://doi.org/10.1080/09593332008616855

[208] Ding, Q., Yamamura, H., Murata, N., Aoki, N., Yonekawa, H., Hafuka, A. and Watanabe, Y. (2016) Characteristics of Meso-Particles Formed in Coagulation Process Causing Irreversible Membrane Fouling in the Coagulation-Microfiltration Water Treatment. Water Research, 101, 127-136. https://doi.org/10.1016/j.watres.2016.05.076

[209] Li, L., Xu, G., Yu, H. and Xing, J. (2018) Dynamic Membrane for Micro-Particle Removal in Wastewater Treatment: Performance and Influencing Factors. Science of the Total Environment, 627, 332-340.

https://doi.org/10.1016/j.scitotenv.2018.01.239

[210] Bahi, A., Shao, J., Mohseni, M. and Ko, F.K. (2017) Membranes Based on Electrospun Lignin-Zeolite Composite Nanofibers. Separation and Purification Technology, 187, 207-213. https://doi.org/10.1016/j.seppur.2017.06.015

[211] Chen, Y.J., Chen, Y.F., Miao, C., Wang, Y.R., Gao, G.K., Yang, R.X., Zhu, H.J., Wang, J.H., Li, S.L. and Lan, Q.L. (2020) Metal-Organic Framework-Based Foams for Efficient Microplastics Removal. Journal of Material Chemistry A, 8, 14644-14652. https://doi.org/10.1039/D0TA04891G

[212] Misra, A., Zambrzycki, C., Kloker, G., Kotyrba, A., Anjass, M.H. Castillo, I.F., Mitchell, S.G., Güttel, R. and Streb, C. (2020) Water Purification and Microplastics Removal Using Magnetic Polyoxometalate-Supported Ionic Liquid Phases (magPOM-SILPs). Angewandte Chemie International Edition, 59, 1601-1605. https://doi.org/10.1002/anie.201912111

[213] Gbric, J., Nguyen, B., Guo, E., You, J.B., Sinton, D. and Rochman, C.M. (2019) Magnetic Extraction of Microplastics from Environmental Samples. Environmental Science \& Technology Letters, 6, 68-72. https://doi.org/10.1021/acs.estlett.8b00671

[214] Wang, L., Kaeppler, A., Fischer, F. and Simmchen, J. (2019) Photocatalytic $\mathrm{TiO}_{2}$ Micromotors for Removal of Microplastics and Suspended Matter. ACS Applied Materials \& Interfaces, 11, 32937-32944. https://doi.org/10.1021/acsami.9b06128 